\title{
Seven new species of cestode parasites (Neodermata, Platyhelminthes) from Australian birds
}

\author{
Jean MARIAUX ${ }^{1, *} \&$ Boyko B. GEORGIEV ${ }^{2}$ \\ ${ }^{1}$ Natural History Museum of Geneva, CP 6434, 1211 Geneva 6, Switzerland. \\ ${ }^{1}$ Department of Genetics and Evolution, University of Geneva, \\ Boulevard d'Ivoy 4, 1205 Geneva, Switzerland. \\ ${ }^{2}$ Institute of Biodiversity and Ecosystem Research, Bulgarian Academy of Sciences, \\ 2 Gagarin Street, 1113 Sofia, Bulgaria. \\ *Corresponding author: jean.mariaux@ville-ge.ch \\ ${ }^{2}$ Email: bbg@ecolab.bas.bg \\ ${ }^{1}$ urn:Isid:zoobank.org:author:B97E611D-EC33-4858-A81C-3E656D0DA1E2 \\ ${ }^{2}$ urn:Isid:zoobank.org:author:88352C92-555A-444D-93F4-97F9A3AC2AEF
}

\begin{abstract}
Cestodes (Platyhelminthes) from Australian birds from the South Australian Museum collections were studied with a focus on common endemic terrestrial hosts. Despite the variable state of preservation of the examined worms, we could identify several new taxa, including Sobolevitaenia whittingtoni sp. nov. and Spiniglans beveridgei sp. nov. (Dilepididae) in Corvus mellori Mathews, 1912 (Corvidae); Notopentorchis musealis sp. nov. (Paruterinidae) in Hirundapus caudacutus (Latham, 1801) (Apodidae); Monopylidium australiense sp. nov. (Dilepididae) in Menura novaehollandiae Latham, 1801 (Menuridae); Dictymetra gerganae sp. nov. (Dilepididae) in Podargus strigoides (Latham, 1802) (Podargidae); Dictymetra longiuncinata sp. nov. in Esacus magnirostris (Vieillot, 1818) (Burhinidae) and Cracticotaenia adelaidae sp. nov. (Metadilepididae) in Gymnorhina tibicen (Latham, 1801) (Artamidae) and Corcorax melanorhamphos (Vieillot, 1817) (Corcoracidae). Several other presumably new taxa that cannot be fully described are also reported. This diversity found in common hosts suggests the presence of a rich, and presently almost completely unknown, fauna of cestode parasites in Australian birds. As field collection permits allowing to explore this fauna are extremely difficult to obtain, this is a demonstration of the usefulness of museum collections to describe at least part of it.
\end{abstract}

Keywords. Dilepididae, Paruterinidae, Metadilepididae, avian hosts, Australian endemics.

Mariaux J. \& Georgiev B.B. 2018. Seven new species of cestode parasites (Neodermata, Platyhelminthes) from Australian birds. European Journal of Taxonomy 440: 1-42. https://doi.org/10.5852/ejt.2018.440

\section{Introduction}

With close to 1000 species, including over one third of endemics, the Australian bird fauna is highly diverse and very particular (Lepage 2017). The cestode parasites of this avifauna, especially those of terrestrial endemic species, remain however very poorly known. In their review, Mawson et al. (1986) 
list about 30 cestode species in these hosts and only a few more have been described more recently (O'Callaghan et al. 2000, 2001). Unfortunately, for administrative reasons, it is presently difficult or even impossible to collect wild birds with the specific objective to survey their parasitological diversity in this country. Thus, the main, or possibly, the single opportunity to study this component of the Australian biodiversity is to access older materials that are conserved in museum collections. Although obviously a second-best option, because of the quality or representativeness of the available material, this approach may allow for some interesting discoveries when old collections have been preserved in good condition. Presently, the single large indigenous Australian parasite collection is maintained in Adelaide in the South Australian Museum (SAMA). It includes historical specimens like those of T.H. Johnston (early $20^{\text {th }}$ Century) or more recent material like those of I. Beveridge. Due to the reasons mentioned above (and possibly also because of the lack of specialists or of recent interest) almost all of the bird parasites in the Adelaide collections are relatively old and part of them is in poor condition. In the course of a visit organized within the framework of a large international collecting effort (Caira et al. 2017), the senior author reviewed this collection, particularly focusing on parasites from Australian endemic species. This allowed for the identification of a number of new taxa that are described below. The fact that a wide variety of novelties were found in a limited number of hosts is a hint that the Australian cestode fauna in birds is most certainly still largely unknown.

\section{Material and methods}

The best available material from hosts of interest was selected during a stay of the senior author at the South Australian Museum, Adelaide, in January 2014. In addition to a small number of stained and mounted specimens, we prepared additional slides from ethanol preserved material using Mayer's hydrochloric carmine staining, dehydration in increasing ethanol series, clearing in eugenol (clove oil) and mounting in Canada balsam. Some scoleces were squashed in Berlese's medium to facilitate examination of rostellar hooks.

All measurements are given in micrometers (if not indicated otherwise) as the range, with the mean and the number (n) of measurements or counts in parentheses. No prevalences are given because these cannot be derived from the available material. Intensities are approximate as most of the material is heavily fragmented. All specimens are deposited in the Australian Helminthological Collections (AHC) at the SAMA. The nomenclature of birds follows the last available edition of Avibase (Lepage 2017).

\section{Results}

The SAMA collection of parasitic helminths holds close to 2000 lots of cestodes of birds, of which we examined around 150 that seemed the best preserved and potentially exploitable for the purpose of this study. Many of those turned out to be in poor condition or consisted of too few specimens for any formal study. In this work, we concentrated on parasites from several groups of terrestrial hosts, mostly Passeriformes like Corvidae, Menuridae, Artamidae and Corcoracidae, as well as from Apodidae (Apodiformes), Podargidae (Caprimulgiformes) and Burhinidae (Charadriiformes). We also focused on birds with a restricted distribution, including endemics, in order to maximize the discovery of novelties. Altogether we report on cestodes from eight different hosts species. Seven new taxa are described and five other, possibly also new but represented by a few or poorly preserved specimens, are also reported. It is likely that a closer examination of the rest of the collection would reveal a larger diversity of unknown taxa. 
Class Cestoda van Beneden, 1848

Order Cyclophyllidea van Beneden in Braun, 1900

Family Dilepididae Fuhrmann, 1907

Genus Sobolevitaenia Spasskaya \& Makarenko, 1965

Sobolevitaenia whittingtoni $\mathrm{sp}$. nov.

urn:1sid:zoobank.org:act:0B872F99-8193-4EC4-AB17-3A3A0FD00D3F

Figs 1-6, Table 1

\section{Etymology}

The species is dedicated to our colleague and friend, the late Professor Ian Whittington, principal research scientist at the South Australian Museum, Parasites Department.

\section{Material examined}

Holotype

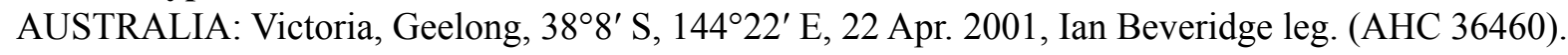

\section{Paratypes}

AUSTRALIA: six specs, same data as for holotype (AHC 36461-36466).

\section{Type host}

Corvus mellori Matthews, 1912 (Passeriformes, Corvidae).

\section{Intensity}

About 55 specimens in a single host, together with $S$. beveridgei sp. nov.

\section{Description}

Body of medium size, with length 40-45 mm and maximum width 890-1050 (985, $\mathrm{n}=6)$ at level of early gravid proglottides. Most complete specimens consisting of 110-115 proglottides. Proglottides craspedote, initially up to twice as wide as long, progressively becoming longer, as long as wide at mature stage and longer than wide at late mature or pregravid stage; gravid proglottides elongating significantly and becoming up to twice longer than wide. Scolex rounded, not delineated from neck, with diameter 260-425 (355, $n=7)$ (Fig. 1). Suckers rounded 116-169 $(144, n=28)$ in diameter; internal surface of suckers armed with large triangular spine-like microtriches, $2-3 \mu \mathrm{m}$ long, arranged in dense regular rows (Fig. 2); microtriches only partly preserved in some specimens. Rostellar apparatus musculo-glandular, with strongly developed glandular tissue within rostellar sac. Rostellar sac well-delineated, tapering posteriorly, extending beyond level of posterior margin of suckers, 275-340 × 110-157 $(304 \times 128$, $\mathrm{n}=7$ ). Rostellum with expanded anterior part bearing rostellar hooks, slightly constricted behind hooks, 172-210 × 81-109 $(191 \times 95, \mathrm{n}=7)$, with thick muscular walls and moderately developed glandular tissue inside it. Rostellar hooks (Fig. 3) in 2 regular rows, 19 (in one worm)-20 ( $n=6)$ in number, robust, handle showing a discrete concave depression at guard level, extremity of handle slightly to markedly bent toward guard. Anterior hooks $42-50(46, \mathrm{n}=22)$, posterior hooks $38-44.5(40.5, \mathrm{n}=21)$. Neck 125-250 $(209, \mathrm{n}=4)$ wide; proglottization distinct at 325-400 $(367, \mathrm{n}=3)$ from posterior margin of suckers. Genital pores lateral, situated in anterior $20-25 \%$ of length of lateral proglottis margin, irregularly alternating in very short series, e.g., 2, 1, 1, 1, 2, 1, 2, 1, 1, 1, 1, 1, 2, 2, 1, 1, 1, 2, 1, 1, 1, 2, $1,1,1$; no more than three consecutive pores observed on a single side. Ventral osmoregulatory canals $11.5-44(23.5, \mathrm{n}=21)$ wide, connected posteriorly in each proglottis by transverse anastomosis. Dorsal osmoregulatory canals $1.5-6(3.5, \mathrm{n}=22)$ wide. Genital ducts passing between osmoregulatory canals. 

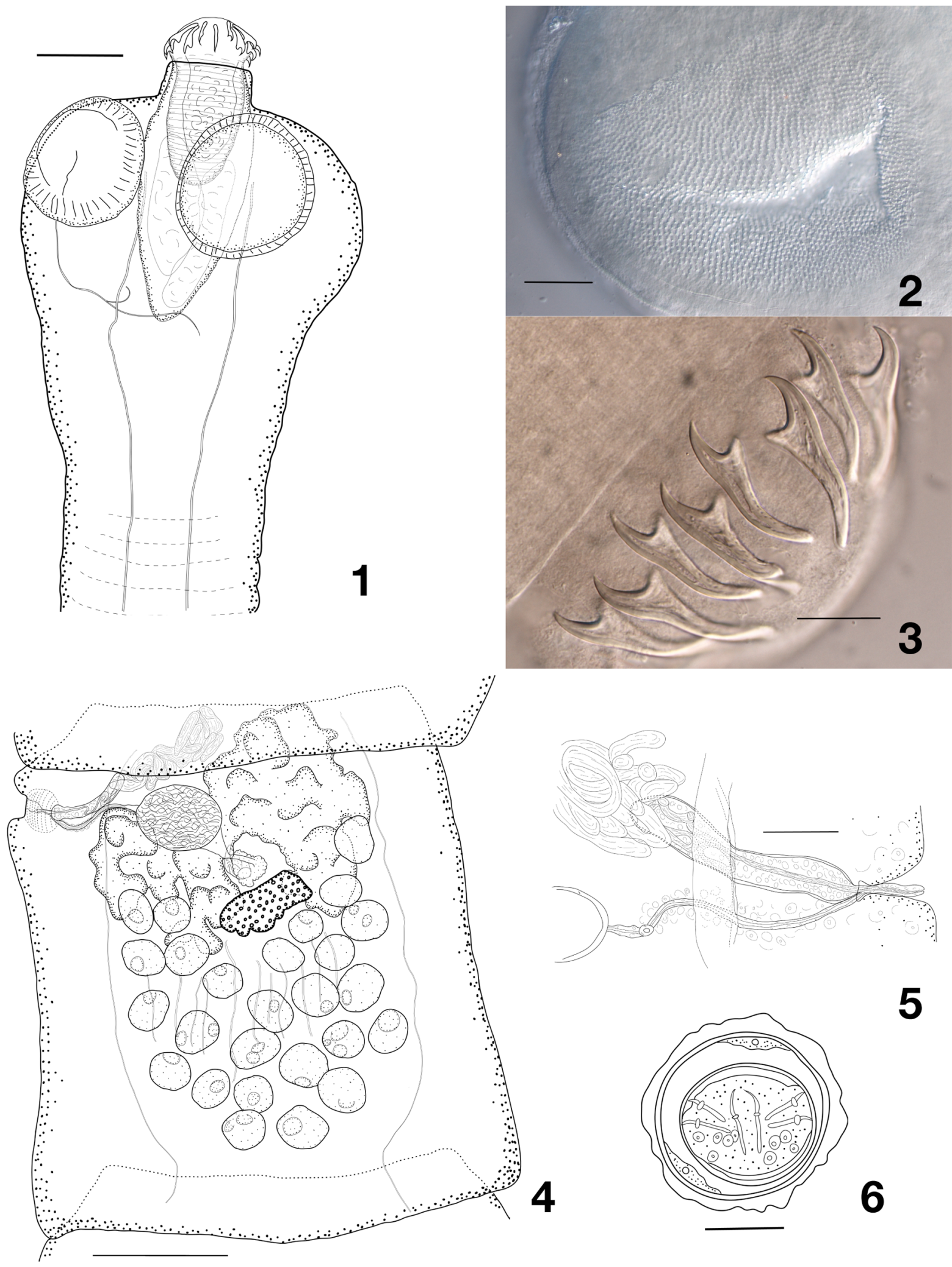

6

Figs 1-6. Sobolevitaenia whittingtoni sp. nov. 1. Scolex. 2. Sucker armament. 3. Hooks. 4. Mature proglottis. 5. Terminal genitalia. 6. Egg. Scale bars: $1=100 \mu \mathrm{m} ; 2,5=50 \mu \mathrm{m} ; 3,6=20 \mu \mathrm{m} ; 4=250 \mu \mathrm{m}$. 
Genital atrium well marked, infundibular or sink-shaped, with slight muscular sphincter, up to about 30-40 deep and 40-50 in diameter. Genital papilla present, often conspicuous.

Testes 20-30 $(24, \mathrm{n}=43)$ in number, in single layer, in one continuous posterior field, extending laterally up to level anterior to vitellarium, not overlapping osmoregulatory canals and often overlapping posterior lobes of ovary (Fig. 4). External vas deferens $16-22$ in diameter $(18.5, \mathrm{n}=20)$, highly convoluted in antero-poral part of median field, sometimes slightly overlapping cirrus-sac. Cirrus-sac elongate, $133-173 \times 23-31(153 \times 27, n=42)$, slightly oblique, often bent anteriorly in proximal part, extending beyond osmoregulatory canals; with slightly-expressed bulb and pipette-like tapering porally and with rounded antiporal end; filled with large cells, more numerous in distal part (Fig. 5). Internal vas deferens forming several (at least 5-6) coils. Cirrus cylindrical, unarmed, 7 in diameter.

Vitellarium central, slightly antiporal to seminal receptacle, lobate, mostly oval and transversely elongated, variable in shape. Ovary transversely elongated, bi-alate, antiporal wing larger than poral wing; occupying all width of anterior third of median field, with lateral branches often overlapping longitudinal osmoregulatory canals; highly lobed, lobes mostly elongate. Mehlis' gland subglobular, $50-62(55, \mathrm{n}=14)$ in diameter, anterior to vitellarium. Empty seminal receptacle round, becoming oval when filled, reaching up to $200 \times 115$, dorsal and between ovary wings or over poral wing, closely posterior to proximal extremity of cirrus-sac. Vagina opened posteriorly to male pore, mostly straight and transverse, parallel to cirrus-sac, sometimes bent posteriorly; lumen of copulatory part thick-walled, surrounded by sleeve of loose, large cells; no vaginal sphincter; conductive part of vagina very short, thin.

Uterus starts its development in late mature proglottides as reticulum situated ventrally to testes and female gonads and occupying entire median field, crossing osmoregulatory canals and lateral parts of it situated in lateral fields. Developing eggs situated in rows mostly by one, rarely in groups of 2-4 eggs along canals of reticulum. Uterine walls persistent even in most developed gravid proglottides, though sometimes become very transparent and difficult for observation. Outer shell of eggs with irregular shape, sometimes not distinct (Fig. 6). Embryophore oval, 37-50 $(42, \mathrm{n}=31)$ in diameter, thick. Oncosphere round to slightly oval, $30-40(33, \mathrm{n}=28)$ in diameter, thick. Embryonic hooks subequal, 11-12 long.

\section{Remarks}

The presence of spines on suckers, the topology of genital organs in mature proglottides, the pattern of the uterine development and the thick embryophore of eggs unambiguously link our material to the genus Sobolevitaenia Spasskaya \& Makarenko, 1965 erected for two species found in Motacillidae in Russia (Spasskaya \& Makarenko 1965). This genus comprises about 15 species found in various passeriform birds, mostly Motacillidae and Turdidae, although Corvidae are also known as hosts (Table 1). Spasskaya \& Spasskii (1977) listed seven species while Kugi (2000) reported 12 species in the genus. Hosts are all from Northern Hemisphere (Spasskaya \& Spasskii 1977; Kugi 2000), except S. korochirei (Voser \& Vaucher, 1988) that has been found in Paraguay (Voser \& Vaucher 1988). Bona (1994), however, noted the probable cosmopolitan distribution of this genus.

Sobolevitaenia spp. have a homogeneous morphology, including about 20 hooks on two rows for most of them. In order to facilitate comparisons and because metrical reports are highly variable for most species (see e.g., Spasskaya \& Spasskii 1977), values from original descriptions are reported as much as possible in Table 1. Most known species show rostellar hooks that are of different size than observed in our material. Furthermore many of them also have a smaller number of testes and (or) cirrus-sacs of different sizes. These characters allow the easy differentiation of our material from the majority of the known Sobolevitaenia spp. (see Table 1). A few remain however more difficult to distinguish: 
Table 1 (continued on next page). Comparison of Sobolevitaenia whitingtoni sp. nov. with the other species of the genus Sobolevitaenia. Notes: * in the original description, the species is found in a second host species, with slight variations in measurements; ** synonym of $S$. anthusi (Spasskaya, 1958) according to Spasskaya \& Spasskii (1977), *** additional measurements in parentheses from Dubinina (1953) in Matevosyan (1963).

\begin{tabular}{|c|c|c|c|c|c|c|c|c|c|c|c|c|}
\hline Species & Host family & $\begin{array}{c}\text { Type } \\
\text { locality }\end{array}$ & $\begin{array}{c}\text { Scolex } \\
\text { diameter }\end{array}$ & $\begin{array}{l}\text { Suckers } \\
\text { diameter }\end{array}$ & $\begin{array}{l}\text { Rostellar } \\
\text { sac }\end{array}$ & Rostellum & $\begin{array}{l}\text { Hooks } \\
\text { number }\end{array}$ & $\begin{array}{c}\text { Anterior } \\
\text { hooks } \\
\text { length }\end{array}$ & $\begin{array}{c}\text { Posterior } \\
\text { hooks } \\
\text { length }\end{array}$ & $\begin{array}{c}\text { Testes } \\
\text { number }\end{array}$ & $\begin{array}{l}\text { Cirrus } \\
\text { sac }\end{array}$ & Source \\
\hline S. whittingtoni sp. nov. & Corvidae & Australia & $260-425$ & $116-169$ & $\begin{array}{c}275-340 \times \\
110-157\end{array}$ & $\begin{array}{l}172-210 \times \\
81-109\end{array}$ & $19-20$ & $42-50$ & $38-44.5$ & $20-30$ & $\begin{array}{c}133-173 \\
\times 23-31\end{array}$ & New data \\
\hline $\begin{array}{l}\text { S. anthusi (Spasskaya, } \\
\text { 1958) (Type species) }\end{array}$ & Motacillidae & Palaearctic & 168 & 72 & $227 \times 74$ & $129 \times 72$ & 20 & $31-33$ & $28-31$ & $16-25$ & $\begin{array}{l}179-184 \\
\times 56-67\end{array}$ & $\begin{array}{l}\text { Spasskaya } \\
\text { \& Spasskii } \\
(1977)\end{array}$ \\
\hline S. iola (Lincicome, 1939) & $\begin{array}{l}\text { Corvidae and } \\
\text { others }\end{array}$ & USA & $244-444$ & $92-127$ & $\begin{array}{c}102-239 \\
\times-\end{array}$ & $-\times 46-97$ & $17-20$ & $26-43$ & $26-43$ & $13-17$ & $\begin{array}{l}122-224 \\
\text { x } 26-40\end{array}$ & $\begin{array}{l}\text { Lincicome } \\
(1939)\end{array}$ \\
\hline S. japonensis Kugi, 2000 & Turdidae & Japan & $250-280$ & $118-120$ & $\begin{array}{l}178-180 \times \\
63-65\end{array}$ & $\begin{array}{l}128-130 \times \\
63-75\end{array}$ & 20 & $48-50$ & $43-45$ & $26-35$ & $\begin{array}{c}98-120 \times \\
15-17.5\end{array}$ & Kugi (2000) \\
\hline $\begin{array}{l}\text { S. korochirei (Voser \& } \\
\text { Vaucher, 1988)* }\end{array}$ & Turdidae & Paraguay & $293-410$ & $82-166$ & - & $\begin{array}{c}148-229 \times \\
64-112\end{array}$ & $20-22$ & $44-56$ & $37-49$ & $14-17$ & $76-114$ & $\begin{array}{l}\text { Voser \& } \\
\text { Vaucher } \\
(1988)\end{array}$ \\
\hline $\begin{array}{l}\text { S. moldavica (Shumilo \& } \\
\text { Spassakaja, 1975) }\end{array}$ & Turdidae & Moldova & 330 & $145 \times 126$ & - & $\begin{array}{l}180-207 \times \\
84-90\end{array}$ & 20 & $45-47$ & $40-42$ & $12-20$ & $\begin{array}{r}160-195 \\
\times 17-22\end{array}$ & Kugi (2000) \\
\hline S. oitaensis Kugi, 1996 & Turdidae & Japan & $480-550$ & $200-250$ & $370 \times 160$ & $190 \times 60$ & 22 & 53 & 43 & $16-17$ & $\begin{array}{l}100-120 \\
\times 25\end{array}$ & Kugi (1996) \\
\hline $\begin{array}{l}\text { S. orientalis Spaskii \& } \\
\text { Konovalov } 1969^{* *}\end{array}$ & Motacillidae & Russia & 225 & 115 & $115 \times 100$ & $170 \times 79$ & 20 & $33-34$ & 31 & $14-18$ & $\begin{array}{l}180-225 \\
\times 39-42\end{array}$ & $\begin{array}{l}\text { Spasskaya } \\
\& \text { Spasskii } \\
(1977)\end{array}$ \\
\hline $\begin{array}{l}\text { S. similis Spasskii \& } \\
\text { Konovalov, } 1969\end{array}$ & Motacillidae & Russia & 205 & $80 \times 95$ & $140 \times 74$ & $125 \times 70$ & 20 & 31 & 25 & $24-28$ & $\begin{array}{r}285-300 \\
\times 42-57\end{array}$ & $\begin{array}{l}\text { Spasskaya } \\
\text { \& Spasskii } \\
(1977)\end{array}$ \\
\hline $\begin{array}{l}\text { S. sobolevi Spasskaya \& } \\
\text { Makarenko, } 1965\end{array}$ & Motacillidae & Russia & 200 & $155 \times 82$ & $173 \times 82$ & $109 \times 45$ & 20 & 19-20 & $19-20$ & 20 & $238 \times 45$ & $\begin{array}{l}\text { Spasskaya \& } \\
\text { Makarenko } \\
(1965)\end{array}$ \\
\hline
\end{tabular}


Table 1 (continued).

\begin{tabular}{|c|c|c|c|c|c|c|c|c|c|c|c|c|}
\hline Species & Host family & $\begin{array}{l}\text { Type } \\
\text { locality }\end{array}$ & $\begin{array}{c}\text { Scolex } \\
\text { diameter }\end{array}$ & $\begin{array}{l}\text { Suckers } \\
\text { diameter }\end{array}$ & $\begin{array}{l}\text { Rostellar } \\
\text { sac }\end{array}$ & Rostellum & $\begin{array}{c}\text { Hooks } \\
\text { number }\end{array}$ & $\begin{array}{c}\text { Anterior } \\
\text { hooks } \\
\text { length }\end{array}$ & $\begin{array}{l}\text { Posterior } \\
\text { hooks } \\
\text { length }\end{array}$ & $\begin{array}{c}\text { Testes } \\
\text { number }\end{array}$ & $\begin{array}{l}\text { Cirrus } \\
\text { sac }\end{array}$ & Source \\
\hline $\begin{array}{l}\text { S. spinosocapite (Joyeux } \\
\& \text { Baer, 1955) }\end{array}$ & $\begin{array}{l}\text { Corvidae and } \\
\text { others }\end{array}$ & France & 370 & 150 & 250 & 60 & $20-30$ & $42-45$ & $37-39$ & $20-23$ & $\begin{array}{r}180-250 \\
\times 25-40\end{array}$ & $\begin{array}{l}\text { Joyeux \& } \\
\text { Baer (1955) }\end{array}$ \\
\hline S. turdi Kugi, 1996 & Turdidae & Japan & 550 & 180 & $340 \times 150$ & $\begin{array}{l}240-270 \\
\times 90\end{array}$ & 16 & 45 & 42 & $17-18$ & $\begin{array}{c}75-80 \times \\
15-18\end{array}$ & Kugi (1996) \\
\hline $\begin{array}{l}\text { S. unicoronata } \\
\text { (Fuhrmann, 1908) }\end{array}$ & Turdidae & Europa & $290-330$ & 130 & $\begin{array}{c}196-308 \times \\
80-112\end{array}$ & $\begin{array}{c}207 \times \\
70-100\end{array}$ & 22 & 48 & 48 & $20-24$ & $140 \times 28$ & $\begin{array}{l}\text { Fuhrmann } \\
\text { (1908) }\end{array}$ \\
\hline $\begin{array}{l}\text { S. verulamii (Mettrick, } \\
\text { 1958) }\end{array}$ & Turdidae & England & $350-370$ & - & - & - & 20 & $63-65$ & $49-53$ & $20-24$ & $240 \times 48$ & $\begin{array}{l}\text { Mettrick } \\
(1958)\end{array}$ \\
\hline $\begin{array}{l}\text { S. (?) borealis (Krabbe, } \\
1869)\end{array}$ & Calcariidae & Greenland & 206 & 79 & - & - & 18 & 30 & 23 & $16-20$ & $\begin{array}{r}136-204 \\
\times 45-57\end{array}$ & Baer (1956) \\
\hline $\begin{array}{l}\text { S. (?) caenodex (Mettrick } \\
\& \text { Beverley-Burton, 1962) }\end{array}$ & Turdidae & England & $290-380$ & $130-140$ & $150 \times 80$ & $-\times 80$ & $18-20$ & $50-54$ & $45-47$ & $20-24$ & $\begin{array}{l}140-180 \\
\times 20\end{array}$ & $\begin{array}{l}\text { Mettrick } \\
\text { \& Burton } \\
(1962)\end{array}$ \\
\hline $\begin{array}{l}\text { S. (?) trigonocephalum } \\
\text { (Krabbe, } 1869) * * *\end{array}$ & $\begin{array}{l}\text { Muscicapidae } \\
\text { and others }\end{array}$ & Greenland & $(200-230)$ & $(80-100)$ & - & - & $20(22)$ & $31-34$ & $\begin{array}{l}31-34 \\
(-35)\end{array}$ & $(12-15)$ & $290 \times 21$ & $\begin{array}{l}\text { Krabbe } \\
(1869)\end{array}$ \\
\hline
\end{tabular}


- Sobolevitaenia iola (Lincicome, 1939), a North American taxon originally reported from Turdus migratorius Linnaeus, 1766 (Turdidae), but also reported from corvids Cyanocitta cristata (Linnaeus, 1758) in Canada (Cooper \& Crites 1974). Although resembling our material, S. iola has fewer testes (13-17), slightly shorter hooks (32 long on average) and an armed cirrus (Lincicome 1939).

- Sobolevitaenia japonensis Kugi, 2000 from Turdus naumanni Temminck, 1820 in Japan has both a smaller rostellar sac $(178-180 \times 63-65)$ and cirrus-sac $(96-120 \times 1518)$ as well as spinose cirrus (Kugi 2000).

- Sobolevitaenia spinosocapite (Joyeux \& Baer, 1955) from various passerines in France, shows a longer cirrus-sac (180-250). Furthermore, Joyeux \& Baer (1955) report up to 30 rostellar hooks in this species. Minute spines are mentioned not only on the suckers but on the whole scolex. Joyeux \& Baer (1955) also reported this taxon from a corvid, Garrulus glandarius (Linnaeus, 1758), but with noticeably different measurements, including longer (50) and more numerous rostellar hooks (25-28).

- Sobolevitaenia unicoronata (Fuhrmann, 1908) from a number of Turdus spp., has hooks of different shape; the length of hooks is similar on both crowns and therefore slightly longer (48) for the second row than those in our material and the double row of hooks is indistinct. Fuhrmann (1908) reported hooks in a single row but Clerc (1911) found them in 2 rows and this point remains contentious. Mettrick's (1958), and numerous other reports of this species in the Palaearctic probably refer to different taxa (Spasskaya \& Spasskii 1977).

Two other species initially described from Greenland by Krabbe (1869) possibly belonging to Sobolevitaenia resemble our material, but their exact generic assignations remain unsettled. However, both $S$. (?) borealis (Krabbe, 1869) and S. (?) trigonocephalum (Krabbe, 1869) have much shorter rostellar hooks and fewer testes. Furthermore $S$. (?) borealis has an armed cirrus (Baer 1956). We conclude that our material differs from all described species of the genus and we recognise it as a new species, Sobolevitaenia whittingtoni sp. nov.

We should, however, consider that the definition of Sobolevitaenia, based essentially on the presence of spines on the suckers, makes the exact content of this genus uncertain as these structures are easily lost or overlooked. The diversity of the genus is thus probably greater than presently known and, possibly, some taxa currently recognised as members of the genus Monopylidium Fuhrmann, 1899 should be reexamined as possible further species of Sobolevitaenia.

The little raven, Corvus mellori, is closely related to C. coronoides Vigors \& Horsfield, 1827. Both are endemic to South and Eastern Australia (Lepage 2017). They are omnivorous and feed predominantly on insects and other soil arthropods among which the intermediate host of $S$. whittingtoni is likely to be found. The cestode fauna of Australian corvids is very poorly known: besides a single full identification of Raillietina corvina (Fuhrmann, 1905) in C. orru Bonaparte, 1850, Mawson et al. (1986) only mention a Hymenolepis sp. in C. mellori, a Davainea sp. in C. coronoides and a few unidentified cestodes. We know seven species of these birds from Australia (Lepage 2017), which must certainly host a much wider diversity of tapeworms.

Genus Spiniglans Yamaguti, 1959

Spiniglans beveridgei $\mathrm{sp}$. nov. urn:1sid:zoobank.org:act:A7F42F63-A54F-4165-BDF1-FE21F47DA734

Figs 7-11, Table 2

\section{Etymology}

The species is dedicated to Professor Ian Beveridge, a friend and colleague, collector of this material, in recognition of his major contribution to systematic helminthology. 


\section{Material examined}

\section{Holotype}

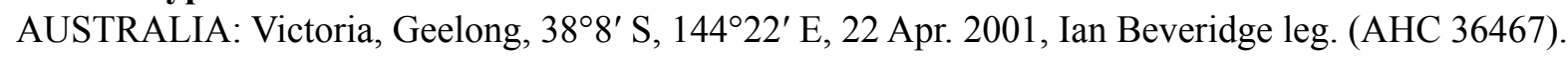

\section{Paratypes}

AUSTRALIA: 10 specs, same data as for holotype (AHC 36468-36477).

\section{Type host}

Corvus mellori Matthews, 1912 (Passeriformes, Corvidae).

\section{Intensity}

About 55 specimens in a single host, together with $S$. whittingtoni sp. nov.

\section{Description}

Body of medium size with length 57-63 mm and maximum width 1050-1280 (1170, $\mathrm{n}=6)$ at level of late mature proglottides. Most complete late mature to pregravid specimens consisting of 169-198 proglottides. Proglottides craspedote, initially wider than long, progressively becoming longer, square at mature stage and longer than wide at late mature stage. Ventral osmoregulatory canals connected posteriorly in each proglottis by transverse anastomosis. Longitudinal musculature with well-marked bundles. Scolex (Fig. 7) rounded, well marked, sometimes showing a transverse fold behind suckers, with diameter 325-450 $(397, \mathrm{n}=6)$. Suckers strong, rounded, $145-180$ in diameter $(161, \mathrm{n}=24)$, unarmed. Rostellar apparatus musculo-glandular, with developed glandular tissue along whole rostellar sac length often slightly protruding apically even when retracted. Rostellar sac well-delineated, 374-450 $\times 132$ $152(383 \times 142, n=6)$ tapering posteriorly, extending beyond level of posterior margin of suckers, often with terminal bubble-like extension. Rostellum oval, strongly muscular, with well-marked constriction behind hooks, 224-270 $\times 85-105(242 \times 94, \mathrm{n}=6)$. Rostellar hooks (Fig. 8) in two mostly regular rows (with occasional slight irregularities or indistinct row delineation), $20(n=1), 21(n=3)$ or $22(n=4)$ in number, robust, with strong guard and slightly bent tapering extremity of handle. Anterior hooks 40.5-44 (42, $\mathrm{n}=8)$, posterior hooks 38.5-40.5 $(39.5, \mathrm{n}=6)$. Proglottization distinct at 500-650 (568, $\mathrm{n}=7$ ) from posterior margin of suckers Genital pores anterior situated at about $20 \%$ of length of lateral proglottis margin, irregularly alternating in short series, e.g., ...1, 1, 2, 2, 1, 1, 3, 1, 1, 2, 2, 3, 1, 4, 5, 3, $1,1,2 \ldots$ No more than five consecutive pores observed on single side. Genital ducts passing between osmoregulatory canals. Genital atrium small.

Testes $40-58(49, \mathrm{n}=54)$ in number (43-55 in $90 \%$ of counts), in one or two layers, in one continuous posterior file, denser posteriorly, mostly extending antero-laterally up to level of vitellarium but a few may be more anterior, especially at antiporal side, occasionally overlapping osmoregulatory canals (Fig. 9). External vas deferens $13.5-21$ in diameter $(17, \mathrm{n}=15)$, highly convoluted in the antero-poral part of proglottis, not overlapping cirrus-sac. Cirrus-sac short, oval or bean-shaped, 87-118 $\times 47-68$ $(102 \times 55, n=44)$, transverse or slightly curved anteriorly, rarely reaching poral osmoregulatory canals. Internal vas deferens coiled, making several large loops within cirrus-sac. Cirrus armed with compact tuft of fine bristle-like spines about 35 long (Fig. 10).

Vitellarium central, transversely elongated, lobate, variable in shape. Ovary transversely elongated, deeply and finely branched, lobulate, bi-alate, antiporal wing much larger than poral one. Mehlis' gland $70-105(84, \mathrm{n}=15)$ closely anterior to vitellarium. Seminal receptacle initially round, rapidly becoming oval, reaching up to $175 \times 114$, dorsal, posterior to external vas deferens, often over poral ovary wing. Vagina thick-walled, along posterior margin of cirrus-sac, mostly straight $7.5-11.5$ in diameter (9.5 

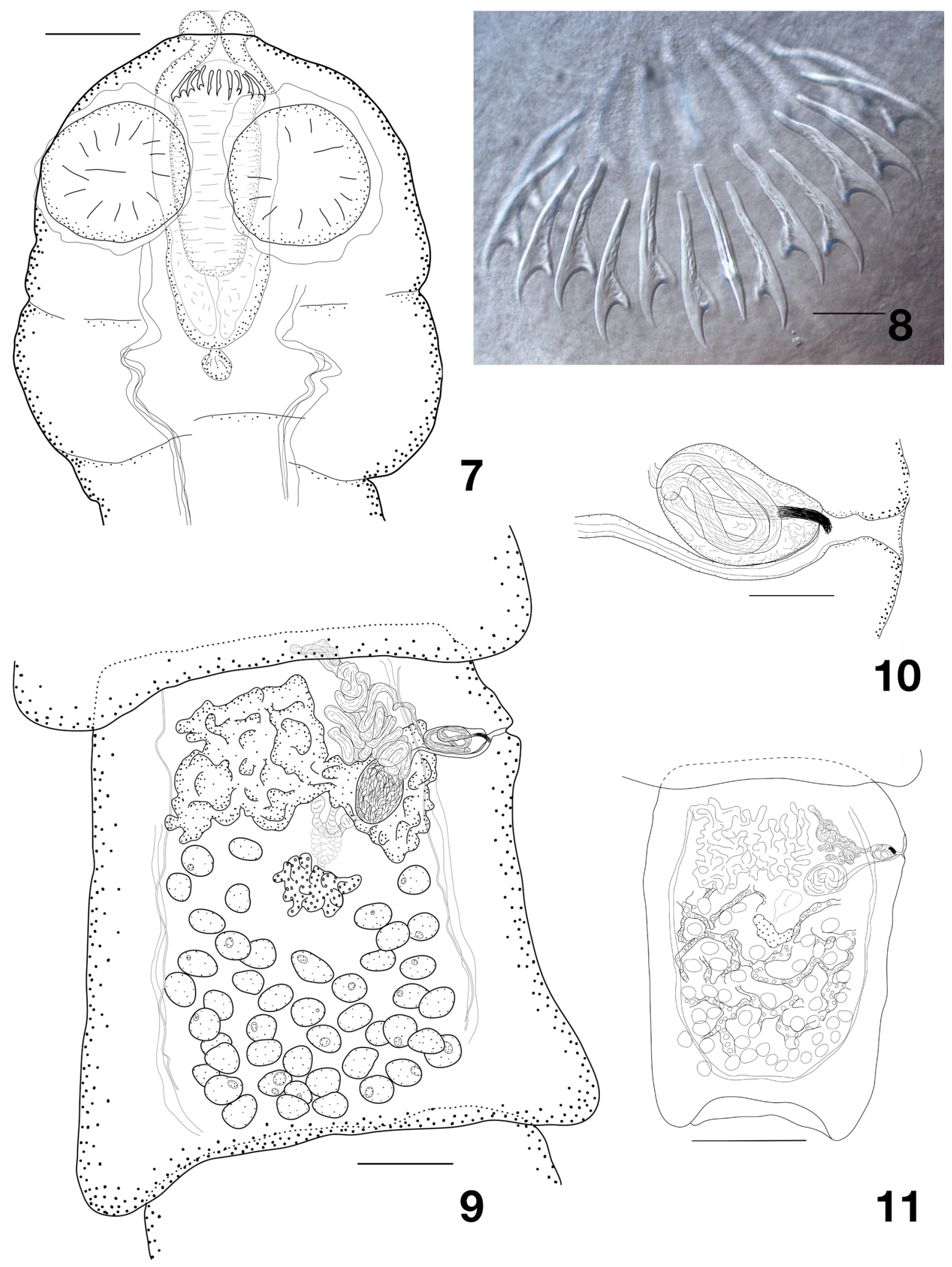

Figs 7-11. Spiniglans beveridgei sp. nov. 7. Scolex. 8. Hooks. 9. Mature proglottis. 10. Terminal genitalia. 11. Pregravid proglottis with young reticular uterus. Scale bars: $7=100 \mu \mathrm{m} ; 8=20 \mu \mathrm{m}$; $9=200 \mu \mathrm{m} ; 10=50 \mu \mathrm{m} ; 11=500 \mu \mathrm{m}$. 
$\mathrm{n}=12$ ), externally gained with loose parenchymal cells. Vaginal pore posterior to pore of cirrus-sac. Young uterus reticular (Fig. 11) in pregravid proglottides. Gravid segments and eggs not observed.

\section{Remarks}

The genus Spiniglans Yamaguti, 1959 has been discussed by Bona (1994), Salamatin (1999) and Kornyushin et al. (2009). The latter authors briefly reviewed the generic characters and listed 4 valid species, from Corvidae in the Old World, as well a few other closely related taxa possibly belonging to the genus. They also predicted that more taxa in this group would be found both in other European and tropical corvid species.

Our material can easily be distinguished from most presently recognized species in the genus (Table 2). It differs from S. microsoma (Southwell, 1922) by having more testes; from S. affinis (Krabbe, 1869) by smaller rostellar hooks, fewer testes and a smaller rostellum; from S. constricta (Molin, 1858) by a larger cirrus-sac, rostellar pouch and rostellum; from S. pirinica (Georgiev, Kornyushin \& Genov, 1987) by much shorter hooks and a smaller cirrus-sac. Our material most closely resembles $S$. sharpiloi Kornyushin et al., 2009 but can be distinguished from it by slightly larger rostellar hooks and a longer rostellar pouch and rostellum. It is also similar to $S$. corvi (Joyeux, Baer \& Martin, 1937) but it has more testes and a shorter cirrus-sac. In consequence, we consider it to belong to a new species, Spiniglans beveridgei $\mathrm{sp}$. nov.

Up to now, Spiniglans was known from the Old World only and its host range essentially limited to the Corvidae although the type species was reported in granivore passerines (Emberizidae and Ploceidae) in captivity (Southwell 1922). Its presence in Australia may be due to a recent importation as Corvus colonized (or re-colonized) this continent after diversifying in the Palaearctic (Ericson et al. 2005; Haring et al. 2012). The Corvidae includes around 130 species and is cosmopolitan. It is therefore expected that a larger diversity of parasites of this genus is still unknown, especially in Asia. It remains to be seen whether New World corvids are also hosts of these cestodes, as hinted by the brief report of Pfaffenberger \& Butler (1981) of S. constricta ("Anomotania constricta") in Corvus cryptoleucus Couch, 1854 in New Mexico. If confirmed, many more Spiniglans spp. are likely to be discovered in American corvids as the family is highly diversified in the Americas.

Genus Neoliga Singh, 1952

\section{Neoliga sp.}

\section{Material examined}

AUSTRALIA: New South Wales, Sydney, 33.48' S, 151 ${ }^{\circ} 6^{\prime}$ E, 2005, Karie Rose leg., 1 spec. in two parts, rather good condition but no gravid proglottides, on same slide as type material of Notopentorchis musealis sp. nov. (AHC 36479); multiple small to minute fragments in bad condition, co-infection with Notopentorchis musealis sp. nov. (AHC 33108).

\section{Host}

Hirundapus caudacutus (Latham, 1801) (Apodiformes, Apodidae).

\section{Description}

The available material is not sufficient to allow for a full description. Scolex 310 in diameter. Suckers weak, oval, 205-220 in diameter. Rostellar pouch $250 \times 125$, weakly muscular. Rostellum $250 \times 100$, bearing an incomplete ( 14 hooks observed, likely $>20$ when complete) double crown of subequal hooks, 46-49 long, with small epyphisis on guard. Genital pores alternating mostly regularly. Testes in single posterior field, in two layers, 23-27 in number. Cirrus-sac very large and strong, reaching antiporal 
Table 2. Comparison of Spiniglans beveridgei sp. nov. with the other species of the genus Spiniglans Yamaguti, 1959.

\begin{tabular}{|c|c|c|c|c|c|c|c|c|c|c|c|c|}
\hline Species & Host & $\begin{array}{c}\text { Type } \\
\text { locality }\end{array}$ & $\begin{array}{c}\text { Scolex } \\
\text { diameter }\end{array}$ & $\begin{array}{l}\text { Suckers } \\
\text { diameter }\end{array}$ & $\begin{array}{l}\text { Rostellar } \\
\text { sac }\end{array}$ & Rostellum & $\begin{array}{c}\text { Hooks } \\
\text { number }\end{array}$ & $\begin{array}{c}\text { Anterior } \\
\text { hooks } \\
\text { length }\end{array}$ & $\begin{array}{l}\text { Posterior } \\
\text { hooks } \\
\text { length }\end{array}$ & $\begin{array}{c}\text { Testes } \\
\text { number }\end{array}$ & $\begin{array}{l}\text { Cirrus } \\
\text { sac }\end{array}$ & Source \\
\hline $\begin{array}{l}\text { S. beveridgei } \\
\text { sp. nov. }\end{array}$ & Corvidae & Australia & $325-450$ & $145-180$ & $\begin{array}{c}374-450 \times \\
132-152\end{array}$ & $\begin{array}{c}224-270 \times \\
85-105\end{array}$ & $20-22$ & $40.5-44$ & $38.5-40.5$ & $40-58$ & $\begin{array}{c}87-118 \times \\
47-68\end{array}$ & New data \\
\hline $\begin{array}{l}\text { S. affinis } \\
\text { (Krabbe, 1869) }\end{array}$ & Corvidae & Ukraine & 550 & 150 & $420 \times 200$ & $350 \times 120$ & 22 & $55-58$ & $50-55$ & $78-86$ & $\begin{array}{c}75-100 \times \\
25-30\end{array}$ & $\begin{array}{l}\text { Salamatin } \\
\text { (1999) }\end{array}$ \\
\hline $\begin{array}{l}\text { S. constricta } \\
\text { (Molin, 1858) }\end{array}$ & Corvidae & Ukraine & 330 & 120 & $250 \times 134$ & $200 \times 120$ & 20 & $40-41$ & $36-37$ & $38-49$ & $\begin{array}{c}60-80 \times \\
30-35\end{array}$ & $\begin{array}{l}\text { Salamatin } \\
\text { (1999) }\end{array}$ \\
\hline $\begin{array}{l}\text { S. corvi } \\
\text { (Joyeux et al., 1937) }\end{array}$ & Corvidae & Somalia & 260 & 170 & $\begin{array}{c}350-430 \times \\
110\end{array}$ & $-\times 160$ & 22 & $43-45$ & - & $32-35$ & $140 \times 50$ & $\begin{array}{l}\text { Joyeux et al. } \\
\text { (1937) }\end{array}$ \\
\hline $\begin{array}{l}\text { S. microsoma } \\
\text { (Southwell, 1922) } \\
\text { (Type species) }\end{array}$ & $\begin{array}{l}\text { Ploceidae, } \\
\text { Emberizidae }\end{array}$ & $\begin{array}{c}\text { India } \\
\text { (Zoological } \\
\text { Garden) }\end{array}$ & 220 & 140 & - & $180 \times 50$ & $16-20$ & 35 & - & $16-20$ & $\begin{array}{l}\text { short and } \\
\text { narrow }\end{array}$ & $\begin{array}{l}\text { Southwell } \\
(1922)\end{array}$ \\
\hline $\begin{array}{l}\text { S. pirinica } \\
\text { (Georgiev et al., } \\
\text { 1987) }\end{array}$ & Corvidae & Bulgaria & $312-406$ & $114-175$ & $\begin{array}{c}344-456 \times \\
144-206\end{array}$ & $\begin{array}{c}262-368 \times \\
87-125\end{array}$ & $20-22$ & $67-73$ & $61-68$ & $39-61$ & $\begin{array}{c}85 \times 110 \times \\
32-45\end{array}$ & $\begin{array}{l}\text { Georgiev } \\
\text { et al. }(1987)\end{array}$ \\
\hline $\begin{array}{l}\text { S. sharpiloi } \\
\text { Kornyushin et al., } \\
2009\end{array}$ & Corvidae & Ukraine & $276-530$ & $130-210$ & $\begin{array}{c}301-350 \times \\
112-220\end{array}$ & $\begin{array}{c}180-200 \times \\
75-110\end{array}$ & $20-22$ & $31-38$ & $28-36$ & $32-45$ & $\begin{array}{c}80-131 \times \\
30-50\end{array}$ & $\begin{array}{l}\text { Kornyushin } \\
\text { et al. }(2009)\end{array}$ \\
\hline
\end{tabular}


excretory canals. Cirrus armed terminally. Vagina opening anteriorly (or dorsally) to cirrus-sac in a wellmarked ductus hermaphroditus connected to deep and wide atrium. Vagina dorsal to cirrus-sac strongly marked, terminating with characteristic sclerotized clamp ["dumb-bell organ", see Bona (1994), or "vaginal sclerites", see Dimitrova et al. (2013)]. Ovary central, deeply multilobulated, with digitiform lobes. Genital ducts dorsal to osmoregulatory canals. Young uterus saccular.

\section{Remarks}

This material belongs to the genus Neoliga Singh, 1952 as defined by Bona (1994), a genus specific to swifts and tree swifts (Apodidae) and known from Morocco to India, Java and Siberia. Four species are listed by Spasskaya \& Spasskii (1977), but the present material does not allow for a detailed comparison. There is no known species of this genus in Australia, but given the migratory pattern of the whitethroated needletail it is quite possible that parasites from Siberian hosts could be found in Australia. This confirms the prediction of Bona (1994) that the genus distribution is probably wider than presently known.

Genus Monopylidium Fuhrmann, 1899

Monopylidium australiense sp. nov. urn:lsid:zoobank.org:act:DB89AB09-63A2-43DB-9F30-5C9D41424955

Figs 12-16, Table 3

\section{Etymology}

The specific name is derived from the country where the material was found.

\section{Material examined}

Holotype

AUSTRALIA: Victoria, Healesville Sanctuary, $37^{\circ} 41^{\prime}$ S, $145^{\circ} 32^{\prime}$ E, 4 Oct. 1994, Peter Holz leg. (AHC 36480, field number 94/773).

Paratypes

AUSTRALIA: about 24 specs, same datas as for holotype (AHC 36481-36486).

\section{Other material}

AUSTRALIA: 2 specs, Victoria, Healesville, 3 Aug. 1991, David Middleton leg. (AHC 22931, 36487);

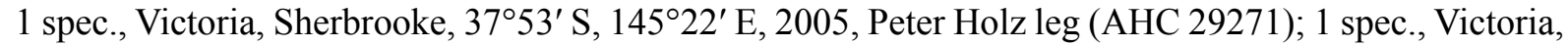
Healesville, 2006, Peter Holz leg. (AHC 29281).

\section{Type host}

Menura novaehollandiae Latham, 1801 (syn. M. superba Dacies, 1820) (Passeriformes, Menuridae).

\section{Site of infection}

Small intestine.

\section{Intensity}

About 25 specimens in a single host.

\section{Description}

Body very small, up to $6.5-8.1(7.3, \mathrm{n}=7) \mathrm{mm}$ long, consisting of 39-53 proglottides; maximum width $600-725(694, \mathrm{n}=9)$ at level of gravid proglottides. Proglottides craspedote, mostly wider 
than long, but shape depending on contraction. Ventral osmoregulatory canals with posterior transverse anastomoses in each proglottis. Strong longitudinal muscular bundles. Scolex 258-305 in diameter $(280, \mathrm{n}=6)$, slightly wider than neck, widest at level of suckers (Fig. 12). Neck poorly or not marked. Suckers elongated, very muscular, with irregular margins, 130-150 in diameter (132, $\mathrm{n}=27$ ). Rostellar pouch strong, musculo-glandular, usually with distinctive widening anterior to suckers, extending beyond level of posterior margin of suckers and becoming much narrower; often folded posteriorly, $270 \times 112(224-320 \times 105-130, \mathrm{n}=6)$. Rostellum muscular, mushroom-shaped 135-150 × 55-83 $(144 \times 73, \mathrm{n}=3)$, with distinct apical pad. Rostellar hooks 20-21 in number, in two regular rows, sub-equal; anterior hooks $23-26(24.2, \mathrm{n}=24)$ long, posterior hooks 22.5-25.0 $(23.7, \mathrm{n}=26)$ long; all hooks of similar shape, with straight handle, strong short guard and very short blade; small epiphyseal-like outgrowth at tip of handle (Fig. 13). Neck short, proglottization distinct at 25-65 $(46, \mathrm{n}=6)$ from posterior margin of suckers. Genital pores at border of first third of lateral proglottis margin, irregularly alternating in short series, rarely more than 2 (maximum observed 4) consecutive pores on a single side. Genital ducts passing between osmoregulatory canals. Genital atrium infundibular.

Testes large, $16-29$ in number $(24, \mathrm{n}=52)$, in median field of proglottis, in double, sometime triple, compact posterior layer, often overlapping vitellarium and ovary. External vas deferens extremely developed, massive and highly convoluted, antero-central, often covering cirrus-sac. Cirrus-sac cylindrical, sometimes slightly wider distally, 86-138 $\times 26-38(113 \times 33, \mathrm{n}=43)$, crossing excretory canals and half of it might be situated in median field (Fig. 14). Cirrus 10-12 in diameter, armed with well developed spines situated on part of it with length 50. Internal vas deferens convoluted.

Vitellarium central, oval, mostly regular, composed of few compact lobes. Ovary central, massive, biwinged, multilobate, filling entire width of median field when fully developed, sometimes even slightly crossing lateral osmoregulatory canals. Mehlis' gland central, overlapping seminal receptacle but not always distinct. Seminal receptacle elongated, anterior to vitellarium and between wings of ovary. Vagina thin-walled with discrete basal muscular sphincter; opening posteriorly to cirrus-sac, sometimes partly overlapping it; lined with thin spines in its distal copulatory part (Figs 14-15).

Uterus initially broadly reticulate, developing quickly over whole median field width and extending in lateral field. With further development, uterus becoming compact, saccular, with few deep lobes. Oncospheres slightly oval, 19-24 $(21, \mathrm{n}=20)$ in diameter. Eggs with thin outer shell provided with two big and distinct nuclei; embryophore spherical, thick (Fig. 16). Central embryonic hooks 11 long, lateral embryonic hooks 10 long.

Observations on additional material (not belonging to the type series)

AHC 22931: about 40, extremely small specimens, shorter than $2 \mathrm{~mm}$, maximum width 510, composed of fewer than 20 proglottides but with extremely rapid development. Some early gravid proglottides present. General characters in accordance with the above description to the exception of slightly wider rostella [85-105 $(95, \mathrm{n}=10)]$ and slight variation in number of rostellar hooks (single specimens with 19,22 or 23 rostellar hooks).

AHC 29271: two slides with fragments of generally poor quality. The observable characters fit the above description.

AHC 29281: a single slide composed of fragments of smaller worms, similar to material from host 22931. Slightly smaller scoleces (200-225 in diameter). 


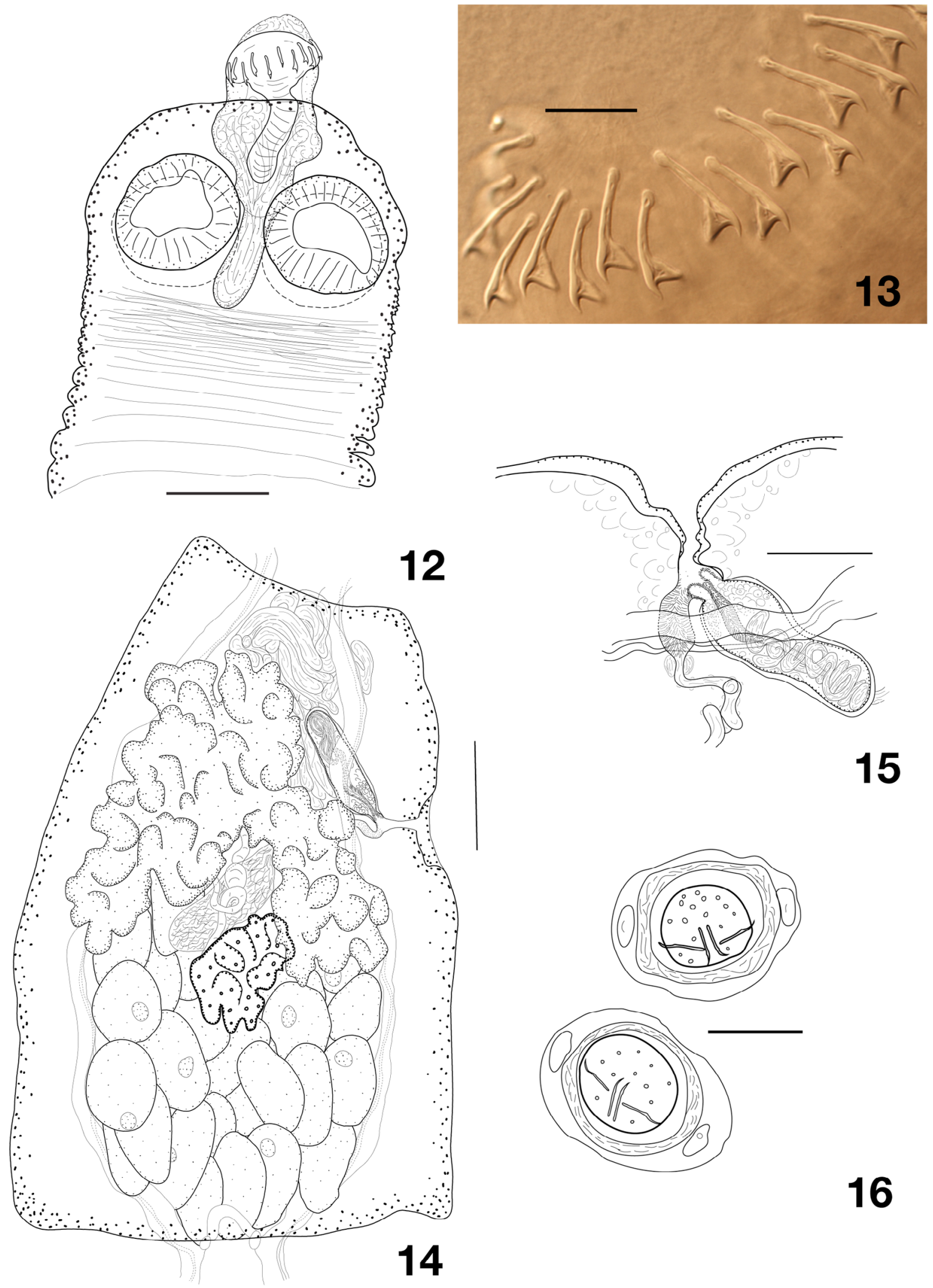

Figs 12-16. Monopylidium australiense sp. nov. 12. Scolex. 13. Hooks. 14. Mature proglottis. 15. Terminal genitalia. 16. Eggs. Scale bars: $12,14=100 \mu \mathrm{m} ; 13,16=20 \mu \mathrm{m} ; 15=50 \mu \mathrm{m}$. 


\section{Remarks}

In its report on helminth parasite of lyrebirds in Australia, Johnston (1913) described a new acanthocephalan but no cestode. Much later, McOrist \& Scott (1989) examined superb lyrebirds suffering from enteritis that was caused by acanthocephalan infections in Southern Victoria and noted the presence of "occasional cestodes of the genus Choanotaenia" in the specimens they studied. To the best of our knowledge, these are the only helminthological reports for these birds.

To our knowledge, there are only two reports of a Monopylidium in Australia. Johnston (1909) mentioned the cosmopolitan species M. passerinum (Fuhrmann, 1907) in Passer domesticus L. in New South Wales and gave a detailed description. This species differed from the present material by several characters including significantly shorter rostellar hooks (Table 3). Monopylidium fieldingi has also been reported from Australia in the butcherbird Cracticus destructor Temminck, 1824 [now C. torquatus (Latham, 1801)] in North Queensland (Maplestone \& Southwell 1923). However, this taxon has a clearly different anatomy, in particular the presence of 80 rose-thorn shaped hooks in two rows, and is now placed in the genus Cracticotaenia Spasskii, 1966 (Metadilepididae) (see below).

Here, we follow the concept of Spasskii (1993) as updated by Bona (1994) for the definition of Monopylidium. Thus, Icterotaenia Railliet \& Henry, 1909 is considered a synonym and some species validated by Spasskii (1993) are now placed in different genera (like Cuculincola Bona, 1994 or Spasspasskya Bona, 1994). Globally, about 25 species of Monopylidum are presently recognized (Table 3), although the status of some of them remains equivocal. Our material can easily be differentiated from nearly all of them, although M. attenuatum (Dujardin, 1845) and M. tandani (Singh, 1964) present relatively similar characteristics. However, the former shows a smaller rostellum bearing hooks of different shape, larger oncospheres and embryonic hooks than those of our specimens. It may also have unarmed cirrus (Spasskaya \& Spasskii 1977). The latter is a short worm with few $(<20)$ proglottides, hooks with longer blades and shorter handles and an unarmed cirrus. It is only known from Myophonus caeruleus temminckii Vigors, 1831, a trush found in the Himalayan region (Singh 1964).

Consequently, Monopylidium australiense sp. nov. is the single known cestode parasitizing this endemic host.

Dilepididae indet.

\section{Material examined}

AUSTRALIA: about 12 specs, Victoria, Healesville Sanctuary, 37²4' S, $145^{\circ} 32^{\prime}$ E, 2002, Dave Middleton leg. (AHC 36488).

\section{Host}

Menura novaehollandiae Latham, 1801 (syn. M. superba Davies, 1802) (Passeriformes, Menuridae).

\section{Description}

This material is in poor state of conservation with contracted and (or) macerated partial strobila and no intact scolex. Scolex width 300-370 $(338, \mathrm{n}=3)$ in diameter; suckers muscular 125-208 $(164, \mathrm{n}=12)$ in diameter. Rostellum 225-255 $\times 85-137$. A single scolex bears an incomplete series of hooks with length 21-25 (23.5, $\mathrm{n}=8$ ) (Fig. 39). Worms are much larger and wider than M. australiense (up to $26 \mathrm{~mm}$ long and $2.6 \mathrm{~mm}$ wide observed, although complete worms should be even larger). The overall 
anatomy is similar, in particular the few observable rostellar hooks are of the same size and shape as in M. australiense, but, among the observable characters, it seems to have more testes (ca 35-40), a vagina lined with setae and a slightly larger cirrus-sac. The cirrus is armed with well-marked small spines. The available material does not allow for a description but hints at the possible diversity of Dilepididae within lyrebirds.

Genus Dictymetra Clark, 1952

Dictymetra gerganae sp. nov. urn:1sid:zoobank.org:act:B01CE7CD-9AB5-4861-9938-9C39350875BB

Figs 17-22, Table 4

\section{Etymology}

The species is dedicated to our friend and colleague, Dr. Gergana Vasileva (Sofia, Bulgaria), a recognized specialist of avian cestodes taxonomy.

\section{Material examined}

Holotype

AUSTRALIA: Tasmania, 16 Oct. 1981, David Obendorf (?) leg. (AHC 36489).

Paratypes

AUSTRALIA: about 14 specs, same data as for holotype (AHC 36490-36494).

\section{Other material}

AUSTRALIA: about 20 very fragmented specs, previously identified as "Choanotoania sp. nov." by R. Wilcox, Victoria, Healesville, 37²1' S, 145³2' E, 20 Mar. 1997, P. Holz leg., 21 Oct. 1997 (AHC 36495).

\section{Host}

Podargus strigoides (Latham, 1802) (Caprimulgiformes, Podargidae).

\section{Site of infection}

Intestine.

\section{Intensity}

About 15 specimens in a single host.

\section{Description}

Body of medium size, with length $65-73 \mathrm{~mm}$ and maximum width $1.88-2.3 \mathrm{~mm}(2.03 \mathrm{~mm}, \mathrm{n}=5)$ at level of gravid proglottides. Most complete specimens consisting of 79-92 proglottides. Proglottides craspedote, wider than long, progressively becoming longer than wide and up to over twice as long as wide when gravid. Osmoregulatory canals mostly indistinct due to the slight maceration of the specimens.

Scolex rounded (Fig. 17), with diameter 305-360 $(\mathrm{n}=2)$. Suckers rounded, 145-175 $(158, \mathrm{n}=8)$ in diameter, smooth. Rostellar apparatus musculo-glandular (Fig. 17). Rostellar sac well-delineated, but weakly muscular, extending beyond level of posterior margin of suckers, 230-292 × 118-145 ( $=4)$. Rostellum heavily muscular with expanded anterior part bearing rostellar hooks, bulb-shaped behind hooks, 195-212 × 98-132 ( $\mathrm{n}=2)$. Rostellar hooks in two regular rows, 24 in number, robust, slightly curved overall, with long blade and handle. Anterior hooks 46-53 when measured on complete scolex $(49.5, \mathrm{n}=6)$ long (see also other material below); posterior hooks, slightly larger and more curved than 
Table 3 (continued on next page). Comparison of Monopylidium australiense sp. nov. with the other species of the genera Monopylidium Fuhrmann, 1899 and Icterotaenia Railliet \& Henry, 1909. See text for the accepted generic concept. Note: * 20, 10 and 19 respectively in original reference, a printing error, as confirmed by the length of cirrus-sac on the original illustration.

\begin{tabular}{|c|c|c|c|c|c|c|c|c|c|c|c|c|}
\hline Species & Host family & $\begin{array}{l}\text { Type } \\
\text { locality }\end{array}$ & $\begin{array}{c}\text { Scolex } \\
\text { diameter }\end{array}$ & $\begin{array}{c}\text { Suckers } \\
\text { diameter }\end{array}$ & $\begin{array}{c}\text { Rostellar } \\
\text { sac }\end{array}$ & Rostellum & $\begin{array}{c}\text { Hooks } \\
\text { number }\end{array}$ & $\begin{array}{c}\text { Anterior } \\
\text { hooks } \\
\text { length }\end{array}$ & $\begin{array}{l}\text { Posterior } \\
\text { hooks } \\
\text { length }\end{array}$ & $\begin{array}{c}\text { Testes } \\
\text { number }\end{array}$ & Cirrus sac & Source \\
\hline $\begin{array}{l}\text { Monopylidium } \\
\text { australiense } \\
\text { sp. nov. }\end{array}$ & Menuridae & Australia & $258-305$ & $130-150$ & $\begin{array}{l}\text { Up to } 320 \\
\quad \times 113\end{array}$ & $\begin{array}{l}135-150 \\
\times 55-83\end{array}$ & $20-21$ & $23-26$ & $22.5-25$ & $20-30$ & $\begin{array}{c}86-138 \times \\
26-38\end{array}$ & New data \\
\hline $\begin{array}{l}\text { M. musculosum } \\
\text { (Fuhrmann, 1896) } \\
\text { (Type species) }\end{array}$ & $\begin{array}{c}\text { Various } \\
\text { Passeriformes }\end{array}$ & $\begin{array}{l}\text { Palaearc- } \\
\text { tic }\end{array}$ & $260-300$ & 90 & - & $70-80$ & $20-22$ & $25-29$ & - & $20-30$ & $\begin{array}{l}180-200 \\
\times 50\end{array}$ & $\begin{array}{l}\text { Spasskaya \& } \\
\text { Spasskii (1977) }\end{array}$ \\
\hline $\begin{array}{l}\text { M. albani } \\
\text { (Mettrick, 1958) }\end{array}$ & Sturnidae & Europe & $320-350$ & $135-150$ & $\begin{array}{c}172-183 \\
\times 101- \\
113\end{array}$ & $\begin{array}{c}98-123 \times \\
55-75\end{array}$ & $25-30$ & $19-23$ & - & $20-28$ & $\begin{array}{c}220-290 \times \\
30-50\end{array}$ & $\begin{array}{l}\text { Komisarovas } \\
\text { et al. ( 2007) }\end{array}$ \\
\hline $\begin{array}{l}\text { Icterotaenia } \\
\text { asymmetrica } \\
\text { (Fuhrmann, 1908) }\end{array}$ & $\begin{array}{l}\text { Caprimulg- } \\
\text { idae }\end{array}$ & Brasil & 290 & 100 & - & - & $20-22$ & 26 & - & 70 & - & $\begin{array}{l}\text { Spasskaya \& } \\
\text { Spasskii (1977) }\end{array}$ \\
\hline $\begin{array}{l}\text { M. attenuatum } \\
\text { (Dujardin, 1845) }\end{array}$ & $\begin{array}{c}\text { Various } \\
\text { Passeriformes }\end{array}$ & Europe & $220-260$ & 95 & - & 78 & 20 & $20-27$ & - & $12-28$ & - & $\begin{array}{l}\text { Spasskaya \& } \\
\text { Spasskii (1977) }\end{array}$ \\
\hline $\begin{array}{l}\text { M. barbara } \\
\text { (Meggitt, 1927) }\end{array}$ & $\begin{array}{l}\text { Corvidae \& } \\
\text { Passeridae }\end{array}$ & India & $200^{*}$ & - & - & $100^{*}$ & 23 & 17 & - & $24-26$ & $190 * \times-$ & Meggitt (1927) \\
\hline $\begin{array}{l}\text { M. binzui } \\
\text { (Yamaguti, 1956) }\end{array}$ & Motacillidae & Japan & 160 & $75-90$ & $150 \times 48$ & $\begin{array}{l}120-130 \\
\times 40-42\end{array}$ & $18(?)$ & 27 & 18 & $14-16$ & $\begin{array}{c}110-230 \times \\
30-45\end{array}$ & $\begin{array}{l}\text { Yamaguti } \\
(1956)\end{array}$ \\
\hline $\begin{array}{l}\text { M. borealis } \\
\text { (Krabbe, 1869) }\end{array}$ & $\begin{array}{c}\text { Various } \\
\text { Passeriformes }\end{array}$ & $\begin{array}{l}\text { Palaearc- } \\
\text { tic }\end{array}$ & 206 & 79 & - & $-\times 68$ & 18 & 30 & 23 & $16-20$ & $\begin{array}{c}136-204 \times \\
45-57\end{array}$ & Baer (1956) \\
\hline $\begin{array}{l}\text { I. columbi } \\
\text { Borgarenko, } 1976\end{array}$ & Columbidae & Tajikistan & 440 & 165 & $275 \times 22$ & $\begin{array}{c}240 \times \\
150\end{array}$ & $34-36$ & $92-106$ & - & $19-22$ & $252 \times 56$ & $\begin{array}{l}\text { Borgarenko } \\
(1981)\end{array}$ \\
\hline $\begin{array}{l}\text { M. dubium } \\
\text { Spasskii \& } \\
\text { Konovalov, } 1986\end{array}$ & Muscicapidae & Chukotka & 280 & 110 & $\begin{array}{c}200-300 \\
\times 79\end{array}$ & $114 \times 45$ & 20 & 24 & - & $14-18$ & $\begin{array}{c}120-170 \times \\
39-44\end{array}$ & $\begin{array}{l}\text { Spasskii \& } \\
\text { Konovalov } \\
(1986)\end{array}$ \\
\hline $\begin{array}{l}\text { M. exiguum } \\
\text { (Dujardin, 1845) }\end{array}$ & $\begin{array}{c}\text { Various } \\
\text { Passeriformes }\end{array}$ & $\begin{array}{l}\text { Palaearc- } \\
\text { tic }\end{array}$ & $150-270$ & $60-100$ & $\begin{array}{r}130-164 \\
\times 89-92\end{array}$ & $\begin{array}{c}40-90 \times \\
51-53\end{array}$ & $24-28$ & $22-25$ & $20-21$ & $10-14$ & $\begin{array}{c}100-184 \times \\
41-49\end{array}$ & $\begin{array}{l}\text { Komisarovas et } \\
\text { al. (2007) }\end{array}$ \\
\hline $\begin{array}{l}\text { I. galbulae } \\
\text { (Gmelin, 1790) }\end{array}$ & $\begin{array}{c}\text { Various } \\
\text { Passeriformes }\end{array}$ & $\begin{array}{l}\text { Palaearc- } \\
\text { tic }\end{array}$ & 410 & 150 & - & 70 & $22-26$ & 30 & 28 & 15 & $\begin{array}{c}140-200 \times \\
40-50\end{array}$ & $\begin{array}{l}\text { Spasskaya \& } \\
\text { Spasskii (1977) }\end{array}$ \\
\hline $\begin{array}{l}\text { M. hamatum } \\
\text { Spasskii, } 1993\end{array}$ & Passeridae & Tuva & 173 & 82 & 191 & 145 & 36 & 17 & - & $18-20$ & $191 \times 40$ & $\begin{array}{l}\text { Spasskaya \& } \\
\text { Spasskii (1977) }\end{array}$ \\
\hline
\end{tabular}


Table 3 (continued).

\begin{tabular}{|c|c|c|c|c|c|c|c|c|c|c|c|c|}
\hline Species & Host family & $\begin{array}{c}\text { Type } \\
\text { locality }\end{array}$ & $\begin{array}{c}\text { Scolex } \\
\text { diameter }\end{array}$ & $\begin{array}{l}\text { Suckers } \\
\text { diameter }\end{array}$ & $\begin{array}{l}\text { Rostellar } \\
\text { sac }\end{array}$ & Rostellum & $\begin{array}{c}\text { Hooks } \\
\text { number }\end{array}$ & $\begin{array}{l}\text { Anterior } \\
\text { hooks } \\
\text { length }\end{array}$ & $\begin{array}{c}\text { Posterior } \\
\text { hooks } \\
\text { length }\end{array}$ & $\begin{array}{c}\text { Testes } \\
\text { number }\end{array}$ & Cirrus sac & Source \\
\hline $\begin{array}{l}\text { M. metamariae } \\
\text { Spasskaya \& } \\
\text { Spasskii, } 1977\end{array}$ & Alaudidae & Murmansk & 450 & 150 & $246 \times 84$ & $230 \times 62$ & 22 & $17-19$ & - & $6-8$ & $62-89 \times 30$ & $\begin{array}{l}\text { Spasskaya \& } \\
\text { Spasskii (1977) }\end{array}$ \\
\hline $\begin{array}{l}\text { I. monedulae } \\
\text { Spasskaya \& } \\
\text { Spasskii, } 1971\end{array}$ & Corvidae & $\begin{array}{l}\text { Tuva, Mol- } \\
\text { davia }\end{array}$ & 440 & 200 & - & $200 \times 172$ & 22 & $19-20$ & 17 & 14 & $\begin{array}{l}165-200 \\
\times 22\end{array}$ & $\begin{array}{l}\text { Spasskaya \& } \\
\text { Spasskii (1977) }\end{array}$ \\
\hline $\begin{array}{l}\text { I. pauciannulata } \\
\text { (Fuhrmann, 1908) }\end{array}$ & Caprimulgidae & Brasil & 450 & 130 & - & - & 16 & 25 & - & 18 & 200 & $\begin{array}{l}\text { Spasskaya \& } \\
\text { Spasskii (1977) }\end{array}$ \\
\hline $\begin{array}{l}\text { M. passerinum } \\
\text { Fuhrmann, } 1907\end{array}$ & $\begin{array}{c}\text { Various } \\
\text { Passeriformes }\end{array}$ & $\begin{array}{l}\text { Palaearctic, } \\
\text { Australia }\end{array}$ & $150-170$ & 80 & - & $110 \times 40$ & 20 & 16 & 14 & $20-30$ & $\begin{array}{l}170-200 \\
\times 40\end{array}$ & Johnston (1909) \\
\hline $\begin{array}{l}\text { M. perisorei } \\
\text { (Spasskaya, 1957) }\end{array}$ & $\begin{array}{l}\text { Corvidae } \\
\text { and other } \\
\text { passerines }\end{array}$ & Palaearctic & 420 & 145 & $\begin{array}{l}\text { Beyond } \\
\text { suckers }\end{array}$ & $\begin{array}{c}108-118 \times \\
40-45\end{array}$ & 20 & $18-19$ & - & 25 & $225 \times 44$ & $\begin{array}{l}\text { Spasskaya \& } \\
\text { Spasskii (1977) }\end{array}$ \\
\hline $\begin{array}{l}\text { M. srivastavai } \\
\text { (Mukherjee, 1965) }\end{array}$ & Turdidae & India & 310 & 100 & - & $130 \times 100$ & 22 & $10-20$ & - & $21-29$ & $\begin{array}{l}100 \times \\
20-30\end{array}$ & $\begin{array}{l}\text { Spasskaya \& } \\
\text { Spasskii (1977) }\end{array}$ \\
\hline $\begin{array}{l}\text { I. tandani (Singh, } \\
\text { 1964) }\end{array}$ & Turdidae & India & $223-312$ & $100-122$ & $160-200$ & $-\times 56-66$ & 20 & $28-32$ & $24-28$ & $19-22$ & $\begin{array}{c}140-160 \times \\
22-24\end{array}$ & Singh (1964) \\
\hline $\begin{array}{l}\text { M. timuri } \\
\text { Borgarenko } 1976\end{array}$ & Alaudidae & Tajikistan & 375 & 174 & $330 \times 160$ & - & $20-22$ & 16 & - & 14-18 & $\begin{array}{l}224-280 \\
\times 60\end{array}$ & $\begin{array}{l}\text { Spasskaya \& } \\
\text { Spasskii (1977) }\end{array}$ \\
\hline $\begin{array}{l}\text { M. trigonocephalum } \\
\text { (Krabbe, 1869) }\end{array}$ & $\begin{array}{l}\text { Passeriformes, } \\
\text { Cuculiformes }\end{array}$ & Palaearctic & $350-380$ & 145-182 & $\begin{array}{c}274-313 \times \\
106-140\end{array}$ & $\begin{array}{l}146-184 \times \\
72-100\end{array}$ & $20-22$ & $32-36$ & - & $18-30$ & $\begin{array}{l}160-190 \\
\times 22\end{array}$ & $\begin{array}{l}\text { Spasskaya \& } \\
\text { Spasskii (1977) }\end{array}$ \\
\hline $\begin{array}{l}\text { M. tugarinovi } \\
\text { (Dubinina, 1950) }\end{array}$ & Muscicapidae & Tajikistan & $170-180$ & $65-75$ & - & - & 20 & $31-32$ & $29-30$ & $10-12$ & To canals & $\begin{array}{l}\text { Spasskaya \& } \\
\text { Spasskii (1977) }\end{array}$ \\
\hline
\end{tabular}


those of anterior row (Fig. 18) (see also other material below). Neck short and weakly marked, 200-250 $(\mathrm{n}=2)$ wide; proglottization distinct at 230-325 $(268, \mathrm{n}=3)$ from posterior margin of suckers. Genital pores anterior, situated at border of anterior $20 \%$ of lateral proglottis margin, irregularly alternating in short series; up to seven consecutive pores observed on one side. Position of genital ducts in relation to excretory canals not observed. Genital atrium small, barely marked. No genital papilla.

Testes $60-77(70, \mathrm{n}=16)$ in number, in single layer with occasional overlaps, in one continuous large field, filling posterior two thirds of median field, extending in anterior direction up to level of vitellarium both porally and antiporally, often more anteriorly, up to level of ovary on antiporal side (Fig. 19). External vas deferens 20-27 in diameter highly convoluted and making compact mass adjacent to cirrussac at level of antiporal wing of ovary; sometimes partially overlapping cirrus-sac and (or) seminal receptacle. Cirrus-sac small, ovoid to pyriform, 100-132 $\times 65-83(115 \times 74, \mathrm{n}=42)$, opening into ductus masculinus surrounded with thin setae (26-36 long), forming a dense terminal tuft (Figs 20-21). Internal vas deferens forming several coils. Cirrus cylindrical, terminally ornate, with long thin setae, mostly difficult to distinguish from those of ductus masculinus.

Vitellarium slightly posterior to level of cirrus-sac, poral to proglottis' midline, antiporal to seminal receptacle, compact and weakly lobate. Ovary small, anterior, slightly poral, bi-alate and lightly lobulate: antiporal wing larger and more anterior than poral wing, at level of vas deferens; poral wing smaller and at level of vitellarium; ovarial wings on both sides of vitellarium. Seminal receptacle elongate, poral to or partially overlapping poral wing of ovary. Vagina opening posteriorly to male pore, most often straight, sometimes slightly bent, rather wide (18-30 in diameter) and short. Vaginal walls regular, bordered externally by loose small cells.

Uterus starts its development in late mature proglottides as reticulum situated ventrally to testes and female gonads and occupying entire median field, crossing osmoregulatory canals and lateral parts of it situated in lateral fields. Outer shell of eggs with irregular shape, sometimes not distinct (Fig. 22). Embryophore oval, 50-65 $(57, \mathrm{n}=20)$ in diameter, thick. Oncosphere round to slightly oval, 28-40 $(33, \mathrm{n}=17)$ in diameter. Central embryonic hooks $20-21.5(20.5, \mathrm{n}=12)$ long, lateral ones 16.5-19.5 $(18, \mathrm{n}=18)$.

\section{Observations on additional specimens}

Although there is no doubt that this material is conspecific with the one described above, we do not include it in the type series due to its poor preservation state. Its observable general characteristics fit the above description with the exception of the occasional presence of well-marked genital papillae. Three hook preparations allowed for more precise observations and measurements of the rostellar armament. We counted 24 hooks on two complete sets, and 20 on an incomplete one. Hooks measuring 48-52 $(49.2, \mathrm{n}=23)$ and $50-56(52.8, \mathrm{n}=26)$ in the anterior and posterior crowns, respectively.

\section{Remarks}

Helminth parasites of frogmouths are virtually unknown. As for tapeworms, the single reported taxon from these birds is Proparuterina aruensis Fuhrmann, 1911 from the Aru Islands in Podargus papuensis (Fuhrmann 1911; Georgiev \& Vaucher 2003). Unidentified cestodes were however more recently reported in P. strigoides in Queensland by Gelis et al. (2011).

Some confusion exists around the systematic organization of dilepidids with cirrus bearing a terminal tuft of long fine spines. According to Bona (1994), they should be distributed in 12 distinct genera and this author provided diagnoses for each of them. By presenting medium-sized strobila, rostellar hooks in two rows, irregularly alternating pores and a reticulate uterus, our material should be placed in Dictymetra Clark, 1952 that has Charadriiformes as 'typical hosts' (Bona 1994). Egg polar processes 

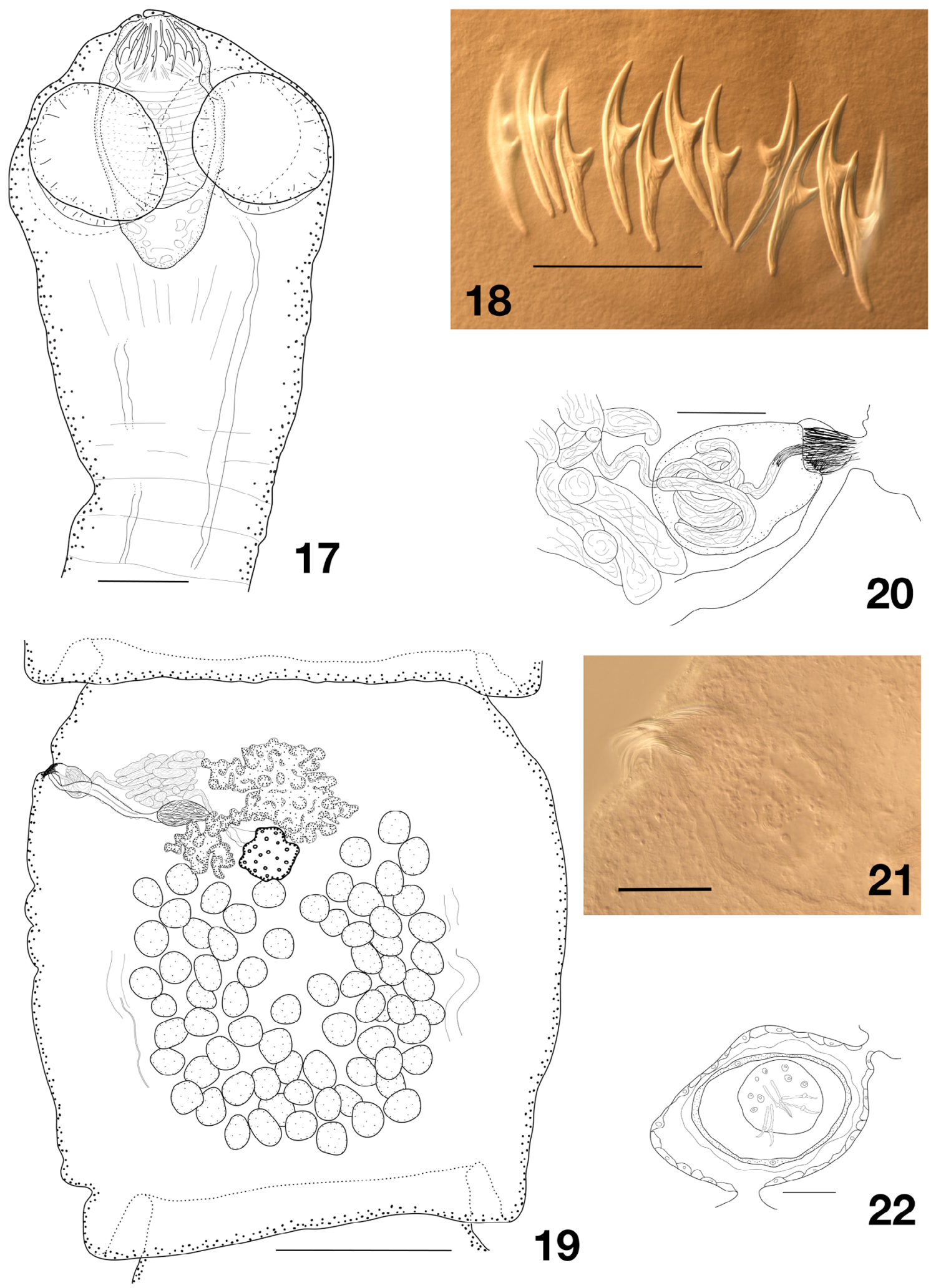

Figs 17-22. Dictymetra gerganae sp. nov. 17. Scolex. 18. Hooks. 19. Mature proglottis. 20. Terminal genitalia. 21. Terminal genitalia tuft. 22. Egg. Scale bars: $17=100 \mu \mathrm{m} ; 18,20,21=50 \mu \mathrm{m} ; 19=500 \mu \mathrm{m}$; $22=20 \mu \mathrm{m}$. 
that are typical of worms with aquatic life-cycles are found in these taxa. It should be noted that other (including terrestrial) birds are also considered by Bona as hosts of members of Dictymetra. They include Passeriformes (for D. belopolskajae Spasskaya \& Spasskii, 1973) and Trogoniformes, although the latter are unpublished. This obviously casts some doubts about the monophyly of the genus.

The genus Dictymetra has been erected by Clark (1952) for cestodes found in North American curlews and has been considered very variably by different authors since then, including as a synonym of Krimi Burt, 1944 (see Matevosyan 1963) or Anomotaenia Cohn, 1900 (see Bona 1975; Schmidt 1986). In the review of the Dilepididae that we follow here, Bona (1994) gives a detailed diagnosis of the genus, which is significantly different from the original one from Clark (1952). In accordance with Spasskaya \& Spasskii (1978), and contrary to Schmidt (1972), he also considers D. radiaspinosa Matevosyan, 1953 (syn. D. numenii Clark, 1952, nec Owen 1949) as its type species.

Liga Weinland, 1857, which is found in terrestrial birds, mostly Piciformes, is another genus with characters close to those of Dictymetra but normally with a small strobila and dorsal genital ducts. Several members of this genus, however, have a longer strobila reaching the size of the present material. For this reason, we compared our material to the presently recognized species of Dictymetra as well as to the "long" Liga spp. (Table 4).

As for Australia, D. adelaidae (Schmidt, 1972) from the spur-winged plover (Lobibyx novaehollandiae Stephens, 1819 now Vanellus miles novaehollandiae) in Queensland was described by Schmidt (1972) as a member of Lapwingia Singh, 1952, which is now considered a synonym of Dictymetra (see Bona 1994). This species does not fit to the diagnosis of Dictymetra and should be place in another genus. Spasskaya \& Spasskii (1978) transferred it to the genus Anomotaenia Cohn, 1900. It is in any case very different from the present material for most usual characters, including the length of hooks (shorter) and number of testes (less numerous).

Our material clearly differs from all recognized species in the genus (Table 4) by several characters, the most obvious being the high number of testes, which is only approached but not matched by D. volvulus (von Linstow, 1906). The latter species has however slightly smaller rostellar hooks and a much shorter cirrus-sac. In consequence, we consider our specimens as belonging to a new species that we name Dictymetra gerganae sp. nov. Even though we are confident that this taxon is new, we should notice that the whole taxonomic organization of this group of genera remains quite uncertain due to the scarcity of reliable information for many species. This will probably lead to their complete revision and the definition of new genera, in which our material may need to be placed in the future.

Dictymetra longiuncinata sp. nov.

urn:1sid:zoobank.org:act:71A5F386-689C-4416-A46C-8FC5078441E4

Figs 23-28

\section{Etymology}

From Latin longus (long) and uncinus (hook) in reference to the large rostellar hooks of this species.

\section{Material examined}

Holotype

AUSTRALIA: Queensland, Yeppoon, 23ㅇ' S, 15044' E, 30 Sep. 1999, Ian Beveridge leg. (AHC 36496).

\section{Paratypes}

AUSTRALIA: about 44 specs, same data as for holotype (AHC 36497-36515). 
MARIAUX J. \& GEORGIEV B.B., Cestodes from Australian birds

\section{Host}

Esacus magnirostris (Vieillot, 1818) (syn. Burhinus magnirostris) (Charadriiformes, Burhinidae).

\section{Site of infection}

Small intestine.

\section{Intensity}

About 45 specimens in a single host.

\section{Description}

Body small, 10.1-13.9 mm $(\mathrm{n}=2)$ long with maximum width 950-1400 $(1144, \mathrm{n}=8)$ at level of early gravid proglottides. Most complete specimen consisting of 76-83 proglottides. Proglottides markedly craspedote, wider than long, progressively becoming longer, but mostly remaining wider than long except for a few terminal or exceptionally extended ones. Osmoregulatory canals only very partially visible. Scolex rounded, in continuity with strobila (without a marked neck); diameter 470-665 (551, n =7) (Fig. 23). Proglottization starting precociously, often just behind suckers. Suckers rounded to slightly oval, muscular, unarmed, 230-300 $(262, \mathrm{n}=32)$ in diameter. Rostellar apparatus mostly muscular, with a layer of glandular tissue at mid-length of rostellar sac. Rostellar sac well-delineated, with cylindrical anterior part and markedly tapering posterior part, extending well beyond level of posterior margin of suckers and sometimes into first proglottides, 475-690 × 150-210 $(608 \times 178, \mathrm{n}=7)$. Rostellum strongly muscular, with expanded anterior part bearing rostellar hooks, 400-620 $\times 110-145(537 \times 133, \mathrm{n}=8)$. Rostellar hooks (Fig. 24) in two regular rows, $20(\mathrm{n}=6)$ in number, long and robust, curved overall; blade longer than handle. Anterior hooks 119-125 (121.5, $\mathrm{n}=13)$ long, posterior hooks 124-135 (129.5, $\mathrm{n}=15$ ) long. Genital pores situated at border of anterior $40 \%$ of lateral proglottis margin, alternating irregularly in very short series, e.g., $1,1,1,1,1,1,2,1,2,1,1,1,1$ or $1,1,2,1,1,3,1,1,1$, 1 ; no more than 3 consecutive pores observed on one side. Genital ducts passing between osmoregulatory canals. Genital atrium as simple depression without particular structures. Genital papilla occasionally expressed in some proglottides.

Testes numerous, $18-28(22, \mathrm{n}=19)$ in number, large, reaching $75-92(84, \mathrm{n}=19)$ in diameter, situated in 2-3 layers, in one continuous and compact posterior field, extending in anterior direction to level of antiporal wing of ovary (Fig. 25). External vas deferens 13-18 in diameter, highly convoluted and particularly voluminous in antero-poral part of median field, sometimes slightly overlapping cirrussac, seminal receptacle or even testes. Cirrus-sac elongate, $137-180 \times 33-45(159 \times 38, \mathrm{n}=44)$, delicate, slightly oblique, usually straight but with distal quarter sometimes bent anteriorly, crossing osmoregulatory canals, rarely not. Internal vas deferens forming several coils. Cirrus cylindrical, 7.5 in diameter, ornamented with tuft of thin hair-like bristles (Figs 26-27).

Vitellarium central, compact, irregularly shaped and slightly lobated. Ovary transversely elongated, bi-alate, lobate, antiporal wing larger than poral wing; the latter mostly covered by vas deferens. Mehlis' gland not observed. Empty seminal receptacle round, becoming oval when filled, reaching up to $135 \times 68$, close to proximal extremity of cirrus sac. Vagina, large, opened posteriorly to male pore, mostly straight and transverse, parallel to cirrus-sac, thin-walled. No sphincters or other ornamentations.

Uterus starts its development in late mature proglottides as diffuse reticulum occupying the whole median field and part of lateral fields, and developing into dense network of tube and chambers. Eggs large, outer shell with polar extensions (Fig. 28). Complete eggs with external membrane difficult to see in utero but reaching at least 85 (without extensions). Embryophores oval, 53-65 $(59.5, \mathrm{n}=15)$ in 
Table 4 (continued on next page). Comparison of two new Dictymetra Clark, 1952 species with the presently recognized species in the genus and with "long" Liga Weinland, 1857 species (see text). All data as reported in Spasskaya \& Spasskii (1978) for Dictymetra and Spasskaya \& Spasskii (1977) for Liga except Burt (1940) for D. dispar, Clark (1952) for D. paranumenii, Fuhrmann \& Baer (1943) for D. riccii and Spasskaya \& Spasskii (1973) for $D$. volvulus. Note that values reported by various authors for $D$. laevigata (Rudolphi, 1919) and $D$. volvulus (Linstow, 1903) vary to a large extent (Spasskaya \& Spasskii 1978). Dictymetra paranumenii and D. radiaspinosa have rows of small spines on rostellum.

\begin{tabular}{|c|c|c|c|c|c|c|c|c|c|c|c|c|}
\hline Species & Host family & $\begin{array}{c}\text { Type } \\
\text { locality }\end{array}$ & $\begin{array}{c}\text { Body } \\
\text { maximum } \\
\text { length }(\mathrm{mm})\end{array}$ & $\begin{array}{c}\text { Scolex } \\
\text { diameter }\end{array}$ & $\begin{array}{l}\text { Suckers } \\
\text { diameter }\end{array}$ & $\begin{array}{l}\text { Rostellar } \\
\text { sac }\end{array}$ & Rostellum & $\begin{array}{c}\text { Hooks } \\
\text { number }\end{array}$ & $\begin{array}{l}\text { Anterior } \\
\text { hooks } \\
\text { length }\end{array}$ & $\begin{array}{l}\text { Posterior } \\
\text { hooks } \\
\text { length }\end{array}$ & $\begin{array}{c}\text { Testes } \\
\text { number }\end{array}$ & $\begin{array}{l}\text { Cirrus } \\
\text { sac }\end{array}$ \\
\hline D. gerganae sp. nov. & Podargidae & Australia & 72 & $305-360$ & $145-175$ & $\begin{array}{c}230-292 \times \\
118-145\end{array}$ & $\begin{array}{c}195-212 \times \\
98-132\end{array}$ & 24 & $46-53$ & $50-56$ & $60-77$ & $\begin{array}{r}100-132 \\
\times 65-83\end{array}$ \\
\hline D. longiuncinata sp. nov. & Burhinidae & Australia & 13.2 & $470-665$ & $230-300$ & $\begin{array}{c}475-690 \times \\
150-210\end{array}$ & $\begin{array}{c}400-620 \times \\
110-145\end{array}$ & 20 & $119-125$ & $124-135$ & $18-28$ & $\begin{array}{r}137-180 \\
\times 33-45\end{array}$ \\
\hline $\begin{array}{l}\text { D. radiaspinosa } \\
\text { Mathevossian, } 1953\end{array}$ & Scolopacidae & USA & $15-25$ & $247-330$ & $204-231$ & - & $83-115$ & 24 & $65-68$ & - & $15-17$ & $\begin{array}{l}146-198 \\
\times 23-25\end{array}$ \\
\hline $\begin{array}{l}\text { D. belopolskajae Spasskaya } \\
\text { \& Spasskii, } 1973\end{array}$ & Alaudidae & $\begin{array}{l}\text { Russian } \\
\text { Arctic }\end{array}$ & 80 & 313 & 123 & $\begin{array}{c}347-408 \times \\
106-123\end{array}$ & $\begin{array}{c}252-308 \times \\
95-112\end{array}$ & 20 & $56-67$ & - & $18-30$ & $\begin{array}{c}106 \times \\
39\end{array}$ \\
\hline $\begin{array}{l}\text { D. discoidea (Beneden, } \\
1868 \text { ) }\end{array}$ & Ciconiidae & Palaearctic & - & $370-400$ & 210 & - & 100 & $22-23$ & $37-38$ & $33-34$ & $40-45$ & $\begin{array}{r}250-270 \\
\times 65-70\end{array}$ \\
\hline D. dispar (Burt, 1940) & Charadriidae & Sri Lanka & $40-50$ & $330-385$ & $143-175$ & $325 \times 110$ & $\begin{array}{c}175-229 \times \\
65-88\end{array}$ & 24 & $41-45$ & $44-49$ & $18-28$ & $\begin{array}{r}170-200 \\
\times 38-41\end{array}$ \\
\hline $\begin{array}{l}\text { D. ganii Spasskaya \& } \\
\text { Shumilo, } 1971\end{array}$ & Scolopacidae & Moldavia & 70 & 695 & 335 & $246 \times 140$ & $162 \times 67$ & $22-24$ & 28 & - & $(\sim 40)$ & $94 \times 67$ \\
\hline $\begin{array}{l}\text { D. laevigata (Rudolphi, } \\
\text { 1819) }\end{array}$ & Charadriiformes & Palaearctic & 75 & 650 & - & 428 & $314 \times 141$ & 20 & $104-106$ & $109-112$ & 50 & $98 \times 48$ \\
\hline D. numenii (Owen, 1946) & Scolopacidae & Holarctic & $14-20$ & $192-538$ & $133-221$ & - & $124-162$ & 22 & $99-103$ & - & $42-46$ & $\begin{array}{r}111-140 \\
\times 44-58\end{array}$ \\
\hline $\begin{array}{l}\text { D. nymphaea (Schrank, } \\
\text { 1790) }\end{array}$ & Charadriiformes & Palaearctic & $25-30$ & $210-220$ & $80-85$ & - & $80-85$ & 24 & $60-80$ & - & $30-36$ & $\begin{array}{r}100-130 \\
\times 38-55\end{array}$ \\
\hline $\begin{array}{l}\text { D. paranumenii (Clark, } \\
\text { 1952) }\end{array}$ & Scolopacidae & USA & $150-300$ & $476-523$ & $143-165$ & $\begin{array}{c}408-620 \times \\
176-204\end{array}$ & $\begin{array}{c}442-516 \times \\
136-176\end{array}$ & 20 & $100-105$ & $110-115$ & $35-40$ & $\begin{array}{r}132-165 \\
\times 33-60\end{array}$ \\
\hline
\end{tabular}


Table 4 (continued).

\begin{tabular}{|c|c|c|c|c|c|c|c|c|c|c|c|c|c|}
\hline & Species & Host family & $\begin{array}{l}\text { Type } \\
\text { locality }\end{array}$ & $\begin{array}{c}\text { Body } \\
\text { maximum } \\
\text { length }(\mathrm{mm})\end{array}$ & $\begin{array}{c}\text { Scolex } \\
\text { diameter }\end{array}$ & $\begin{array}{l}\text { Suckers } \\
\text { diameter }\end{array}$ & $\begin{array}{l}\text { Rostellar } \\
\text { sac }\end{array}$ & Rostellum & $\begin{array}{c}\text { Hooks } \\
\text { number }\end{array}$ & $\begin{array}{l}\text { Anterior } \\
\text { hooks } \\
\text { length }\end{array}$ & $\begin{array}{l}\text { Posterior } \\
\text { hooks } \\
\text { length }\end{array}$ & $\begin{array}{c}\text { Testes } \\
\text { number }\end{array}$ & $\begin{array}{l}\text { Cirrus } \\
\text { sac }\end{array}$ \\
\hline & $\begin{array}{l}\text { D. riccii (Fuhrmann \& } \\
\text { Baer, 1943) }\end{array}$ & Ciconiidae & Africa & $35-40$ & 400 & 240 & - & $400 \times 72$ & 24 & $96-100$ & - & $20-22$ & $\begin{array}{c}115-126 \\
\times 39\end{array}$ \\
\hline & $\begin{array}{l}\text { D. volvulus (Linstow, } \\
\text { 1906) }\end{array}$ & Charadriiformes & Palaearctic & 60 & $275-26$ & - & - & $125 \times 67$ & $24-26$ & 45 & 48 & $40-60$ & $\begin{array}{l}75-85 \\
\times 45\end{array}$ \\
\hline & \multicolumn{13}{|l|}{ Liga } \\
\hline & L. centuri (Rysavy, 1966) & Picidae & Cuba & $22-47$ & $370-390$ & $198-228$ & - & $\begin{array}{c}234-260 \times \\
104-137\end{array}$ & $18-20$ & $62-64$ & one row & - & $\begin{array}{r}92-122 \\
\times 60-68\end{array}$ \\
\hline U & $\begin{array}{l}\text { L. crateriformis (Goeze, } \\
1782 \text { ) }\end{array}$ & Picidae & Palaearcic & $18-25$ & $275-430$ & $109-173$ & $229-240$ & $\begin{array}{c}136-229 \times \\
70-73\end{array}$ & $28-35$ & $27-35$ & - & $16-35$ & $\begin{array}{r}64-145 \\
\times 40-55\end{array}$ \\
\hline & L. pici (Baer, 1959) & Picidae & D.R. Congo & 15 & $160-190$ & $98-102$ & - & $-\times 45-50$ & 26 & $17-18$ & - & $38-40$ & $\begin{array}{r}68-91 \\
\times 34-45\end{array}$ \\
\hline & L. picusi (Singh, 1964) & Picidae & India & $19.5-26.2$ & $370-490$ & $130-150$ & $\begin{array}{c}270-310 \times \\
134-140\end{array}$ & $\begin{array}{c}-\times \\
80-100\end{array}$ & $\mathrm{I} 30$ & $46-54$ & one row & $25-30$ & $\begin{array}{r}120-200 \\
\times 32-40\end{array}$ \\
\hline
\end{tabular}

Liga

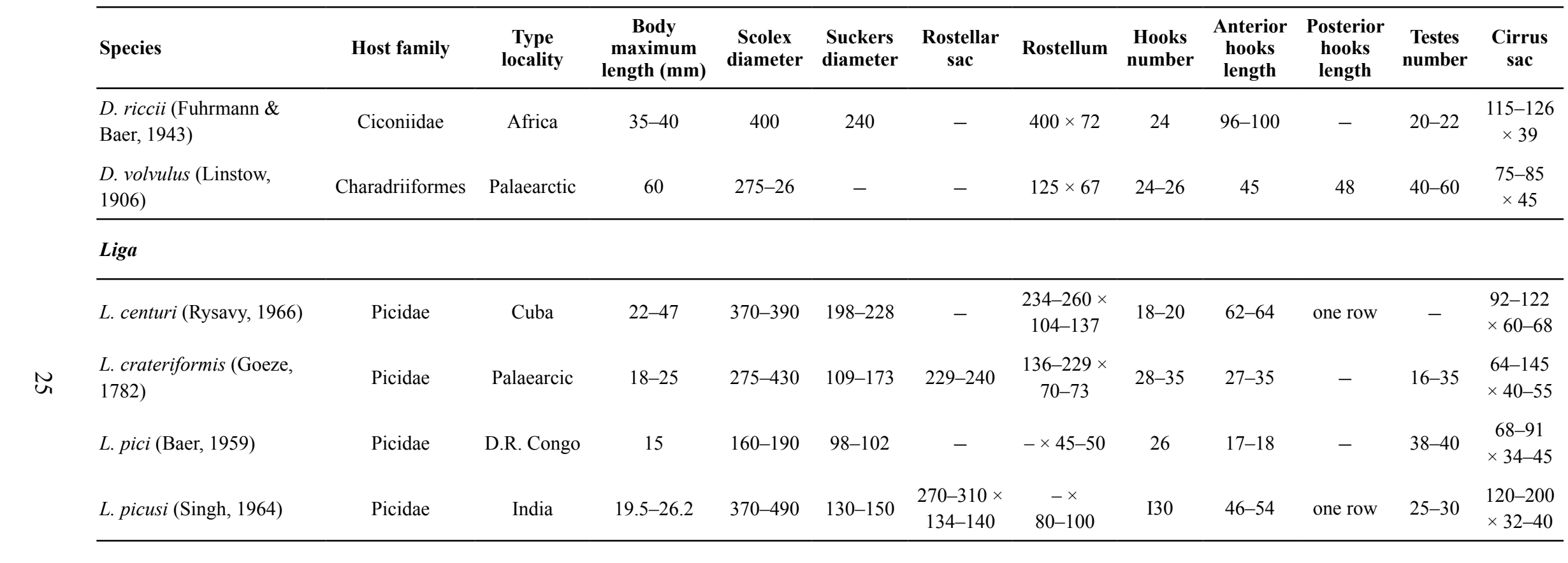



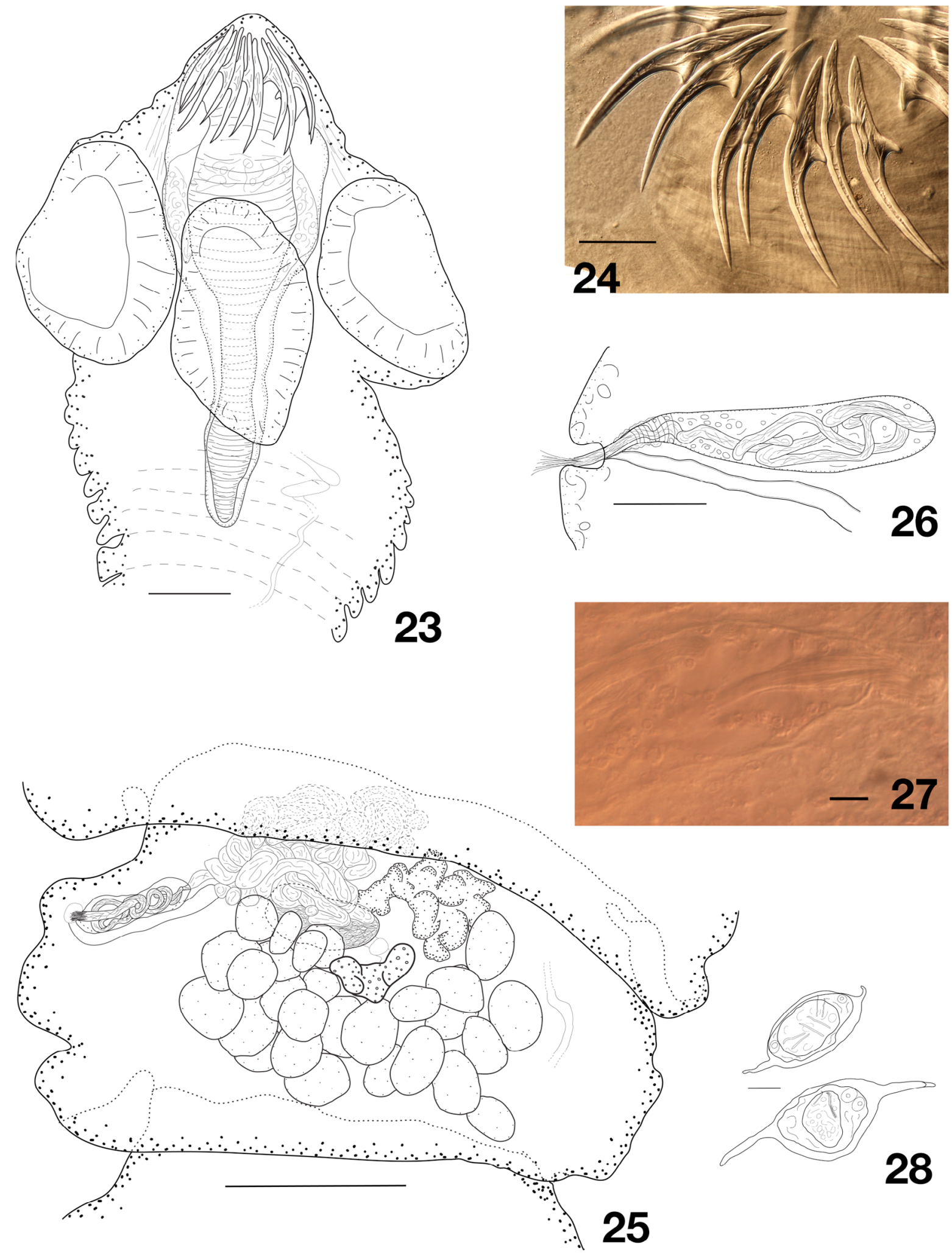

Figs 23-28. Dictymetra longiuncinata sp. nov. 23. Scolex. 24. Hooks. 25. Mature proglottis. 26. Terminal genitalia. 27. Cirrus armament. 28. Eggs. Scale bars: $23=100 \mu \mathrm{m} ; 24,26=50 \mu \mathrm{m} ; 25=200 \mu \mathrm{m}$; $27=10 \mu \mathrm{m} ; 28=20 \mu \mathrm{m}$. 
diameter. Oncospheres 38-46 $(42, \mathrm{n}=22)$ in diameter. Embryonic hooks: central 20-21.5 $(21, \mathrm{n}=8)$ long, lateral $17-20(19, \mathrm{n}=16)$ long.

\section{Remarks}

This material is partly macerated, with many fragments contracted and overall in an average state of conservation. This explains the lack of data for several characters such as osmoregulatory canals or Mehlis' gland. Our observations, nevertheless, allow for a description that fits the definition of Dictymetra, in particular because of its characteristic scolex structure and tuft of setae in the genital atrium and on the cirrus. The genus Dictymetra is typically found in various families of Charadriiformes, including Burhinidae (Bona 1994) (see remarks above for D. gerganae sp. nov.) and is cosmopolitan (Table 4). Our material can easily be differentiated from other species in the genus because of its very long hooks and large rostellum. Similar characters are only found in D. laevigata (Rudolphi, 1919), another parasite of thick-knees, and D. paranumenii (Clark, 1952), a parasite of curlews in North America. It differs from both by its smaller number of testes. Additionally, it can be distinguished from the former species by its larger cirrus-sac, and from the latter by its shorter strobila (Table 4).

In addition, the genus Stenovaria Spasskii \& Borgarenko, 1973 also resembles our material. It differs from Dictymetra by relatively minor characters related to genital pore alternation, the position of genital ducts in relation to osmoregulatory canals and the absence of armament of long setae on the cirrus and (or) genital atrium. The genus was erected by Spasskii \& Borgarenko (1973) and is presently recognized as valid (Bona 1994, Mariaux et al. 2017). It includes 2 species found in thick-knees: Stenovaria facile (Meggitt, 1927) Spasskaya \& Spasskii, 1978 and S. falsificata (Meggitt, 1927) Spasskii \& Borgarenko, 1973 that deserve to be compared to our material. Both differ from it by their much shorter hooks and smaller strobila. In addition, the former species also shows a smaller cirrus-sac and the latter has a larger cirrus-sac and a smaller number of testes. In consequence we consider the present material as a new species that we name Dictymetra longiuncinata sp. nov.

\section{Dictymetra sp.}

\section{Material examined}

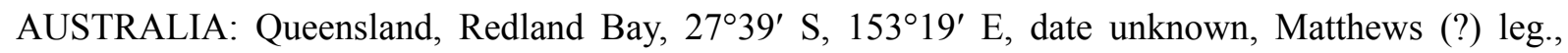
fragments from 2 specs (AHC 35795, AHC 35796).

\section{Host}

Burhinus grallarius (Latham, 1802) (Charadriiformes, Burhinidae).

\section{Site of infection}

Small intestine.

\section{Description}

Despite its similarity with the above described new species, this material probably belongs to another congeneric species. The available mounted specimens do not however allow for a detailed description. From the single scolex and few fragments available, the hook arrangement is similar to that of D. longiuncinata but hooks are somewhat larger (about $145 \mathrm{long})$. The rostellar sac $(320 \times 140)$ and rostellum $(270 \times 90)$ are smaller. It also has a cirrus armed with long setae but has a higher number of testes, i.e., $29-45(37, \mathrm{n}=12)$ - and a smaller cirrus-sac, $107-113 \times 25-28(110 \times 27, \mathrm{n}=4)$. It most probably belongs to Dictymetra but additional fresh material is obviously needed to confirm its status. 
Dilepididae indet.

Fig. 39

\section{Material examined}

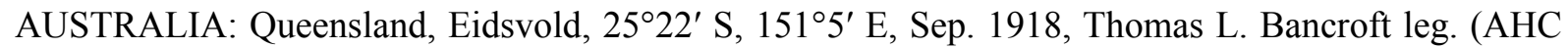
36528).

Host
Corcorax melanorhynchos (Vieillot, 1817) (Passeriformes, Corcoracidae).

\section{Site of infection}

Small intestine.

\section{Intensity}

About 8 specimens.

\section{Description}

A few fragmented specimens of this species are found as co-parasites of Cracticotaenia adelaidae sp. nov. in our material from Queensland. Unfortunately, hooks are lost on the single available scolex. Longest fragment $13 \mathrm{~mm}$, maximum width $1.4 \mathrm{~mm}$ at level of gravid proglottides. Up to 61 craspedote proglottides, wider than long except for the most gravid ones. Scolex not clearly separated from strobila, 227 in diameter. Suckers rounded $97-115$ in diameter. Rostellar pouch very glandular, $167 \times 70$, extending past posterior margin of suckers. Rostellum muscular, with well-marked terminal pad, $132 \times 72$. Neck not marked. Genital pores, opening laterally and very anteriorly, at about $15 \%$ of lateral proglottis margin, alternating irregularly in short series. Ventral osmoregulatory canals connected posteriorly in each proglottis by transverse anastomosis. Genital ducts passing between osmoregulatory canals. Testes $17-23(19.7, \mathrm{n}=26)$ in number, in a single layer and one continuous posterior field, extending antero laterally up to level of vitellarium. Cirrus-sac short and weak, 76-92 $\times 30-42$, not reaching poral osmoregulatory canals. Cirrus armed with a small tuft of setae, often lost in our material. Vitellarium central, compact. Ovary anterior transversely elongated. Seminal receptacle rounded, lateral to vitellarium. Vagina posterior to male pore. Uterus initially labyrinthic. No fully gravid proglottides observed.

Family Hymenolepididae Perrier, 1897

Genus Passerilepis Spasskii \& Spasskaya, 1954

Passerilepis (?) sp.

Fig. 40

\section{Material examined}

AUSTRALIA: Victoria, Kangaroo Grounds, 37²42' S, $145^{\circ} 12^{\prime}$ E, 1979, Karl Harrigan leg. (AHC 36527).

\section{Host}

Corcorax melanorhynchos (Vieillot, 1817) (Passeriformes, Corcoracidae).

\section{Intensity}

About 6 specimens. 


\section{Description}

Although several specimens of this species are available, including almost complete ones, just a single squashed scolex is present and the material is highly macerated, thus preventing a full description. Longest fragment $38 \mathrm{~mm}$, maximum width $1.6 \mathrm{~mm}$ at level of gravid proglottides. Ten hooks on a single crown, 24-25 long, with short blade, robust guard and slightly curved handle (Fig. 40). Three testes arranged in triangle, 2 antiporal. Cirrus-sac crossing osmoregulatory canals dorsally, about 165185 long. Genital openings unilateral, dextral. Both seminal vesicles and seminal receptacles inflating considerably. Uterus initially bisaccular, becoming unisaccular with deep lobes. Oncosphere 45-50. Embryonic hooks 20-22 (lateral), 22-24 (central). These few available characters hint toward the genus Passerilepis Spasskii \& Spasskaya, 1954 (Hymenolepididae).

Family Paruterinidae Fuhrmann, 1907

Genus Notopentorchis Burt, 1938

Notopentorchis musealis sp. nov. urn:1sid:zoobank.org:act:99114137-DA7B-47EE-996F-49005C2B8A07

Figs 29-33, Table 5

\section{Etymology}

The species name refers to the fact that this species is described from museum material.

\section{Material examined}

\section{Holotype}

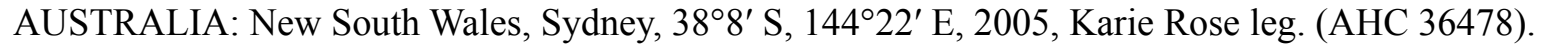

\section{Paratype}

AUSTRALIA: same data as for holotype (AHC 36478).

\section{Intensity}

Two specimens and a few small fragments. Co-infection with Neoliga sp.

\section{Description}

Body of medium size, with maximum length $34 \mathrm{~mm}$ for 404 proglottides; maximum width 590, at level of gravid proglottides. Proglottides craspedote, all but the few most developed (pre-gravid) ones wider than long. Ventral osmoregulatory canals connected posteriorly in each proglottis with transverse anastomosis. Scolex slightly rounded, not distinctly separated from neck, with diameter 248-345 ( $\mathrm{n}=2)$. Suckers elongated $170-215$ in diameter $(182, \mathrm{n}=7)$. Rostellum very muscular, sucker-like, slightly concave anteriorly and conical posteriorly, 114-139 in diameter and 107-125 long $(\mathrm{n}=2)$ (Fig. 29). Rostellar hooks mostly lost (probably several tens, only 7 remaining), in two rows, subequal, $21-23$ in length $(22, \mathrm{n}=5)$. Posterior hooks with slightly more curved handle than anterior hooks (Fig. 30); guard bifid. Small epiphyses on both guards and handles. Neck long; proglottization distinct at 475 from posterior margin of suckers. Genital pores at mid-length of lateral proglottis margin, irregularly alternating in short series, maximum 5 consecutive pores observed on one side. Ventral osmoregulatory canals connected posteriorly in each proglottis by single transverse anastomosis. Genital ducts passing ventrally to osmoregulatory canals. Genital atrium cup-shaped, voluminous.

Testes large, spherical, 5-8 $(6.5, \mathrm{n}=11)$ in number, in single posterior and dorsal layer, often overlapping vitellarium and posterior parts of ovary, occasionally overlapping longitudinal 

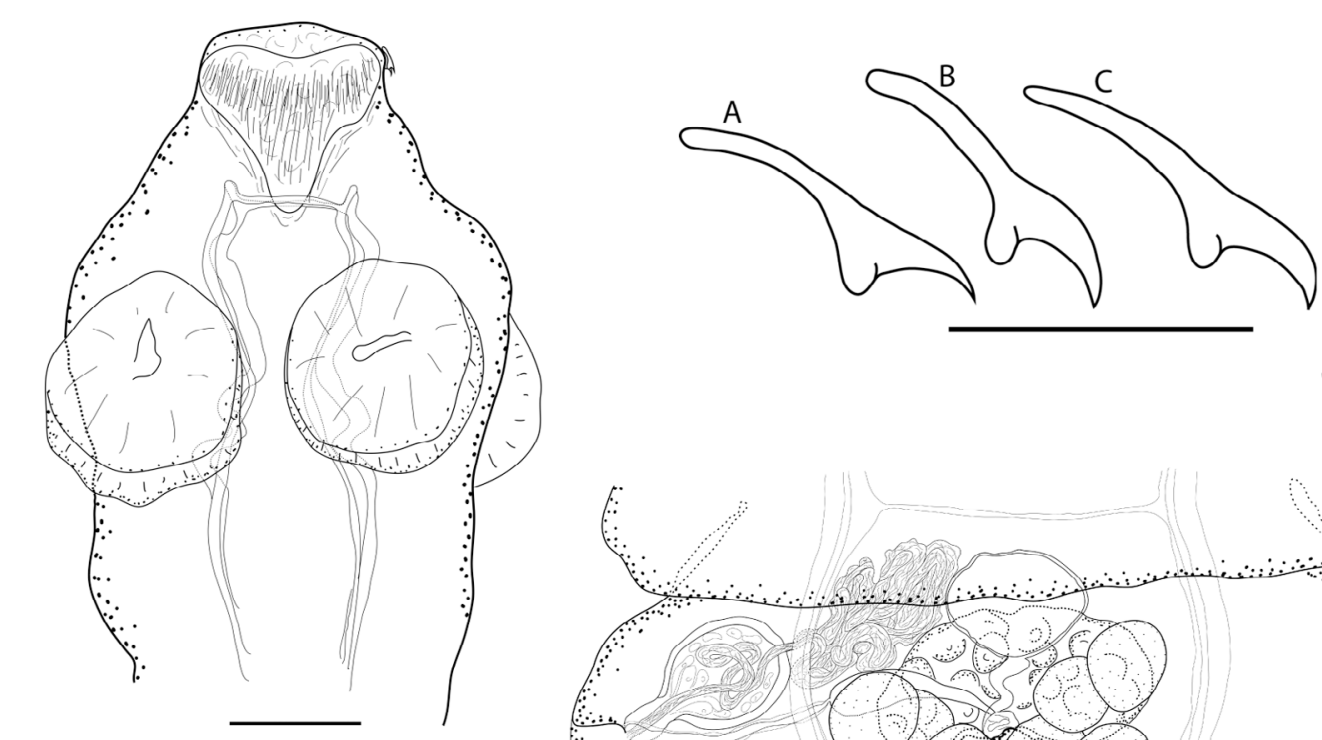

29
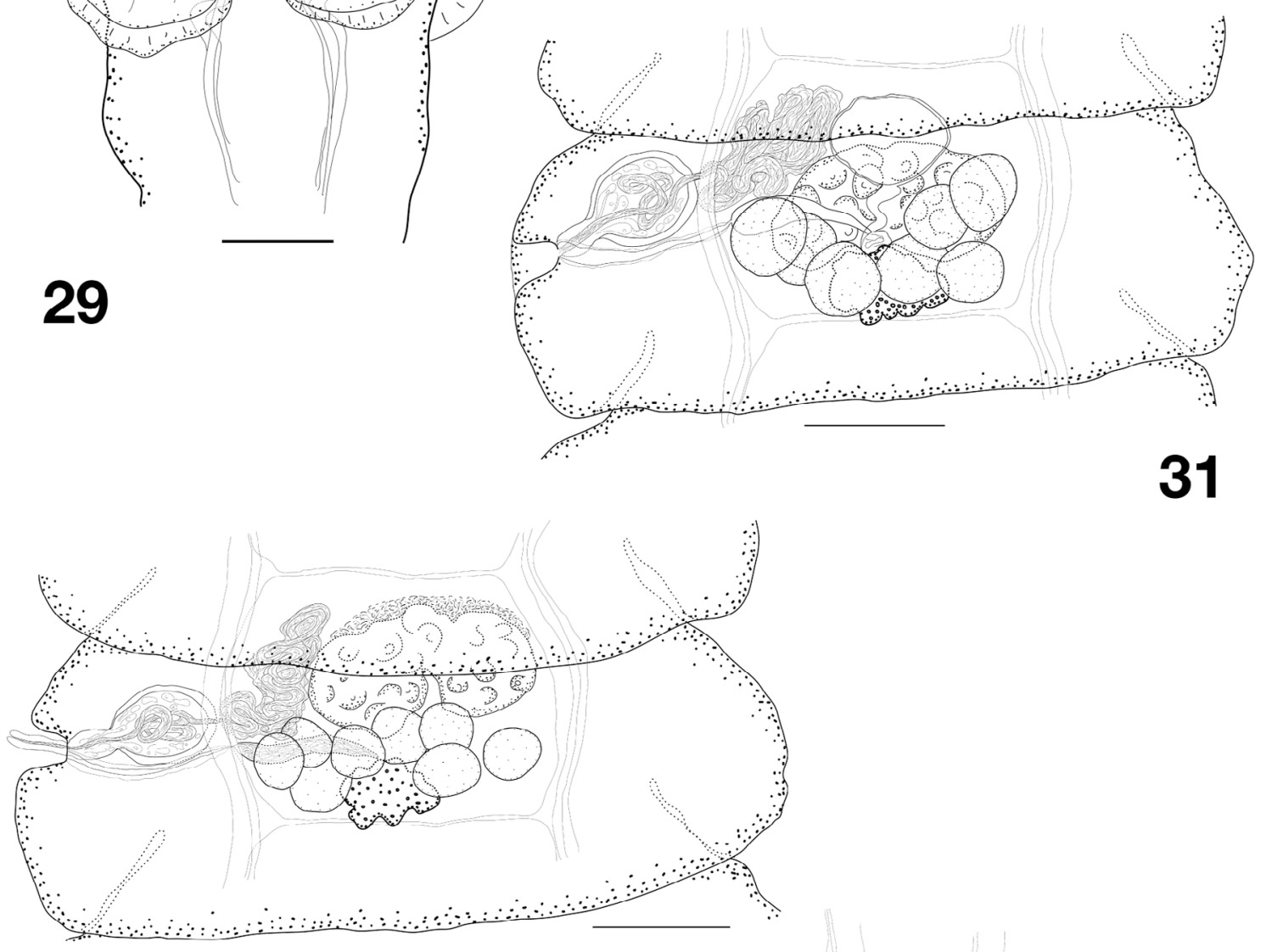

32

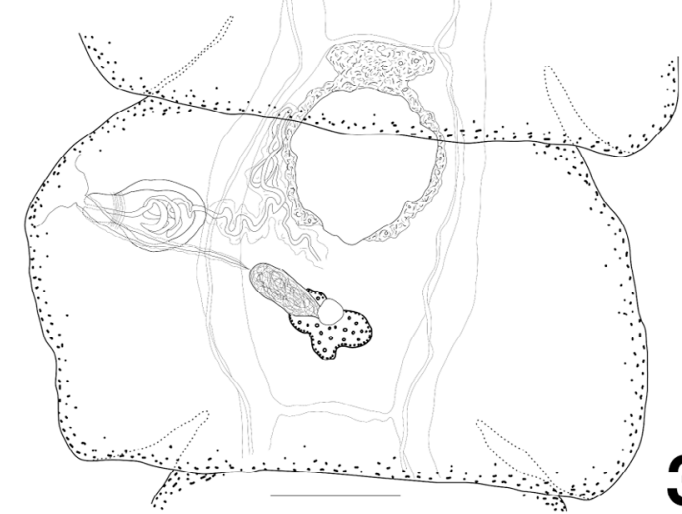

Figs 29-33. Notopentorchis musealis sp. nov. 29. Scolex. 30. Hooks: A, C. Anterior hooks, B. Posterior hook. 31. Mature proglottis. 32. Postmature proglottis. 33. Pregravid proglottis. Scale bars: $29,31-33=100 \mu \mathrm{m} ; 30=20 \mu \mathrm{m}$. 
osmoregulatory canals. External vas deferens convoluted antero-porally, poral to developing uterus surrounded by intensely-stained cells and forming together with them dense mass in anteroporal part of median field. Cirrus-sac 91-112 $\times 54-64(105 \times 59, \mathrm{n}=15)$, consisting of narrower, almost cylindrical, distal part and spherical thick-walled proximal part, often overlapping poral osmoregulatory canals; internal vas deferens coiled in proximal part of cirrus-sac. Cirrus cylindrical, unarmed, 10-12 in diameter.

Vitellarium oval, massive, mostly irregular, 55-76 $\times 40-50(68 \times 46, \mathrm{n}=10)$, situated adjacent to posterior proglottis margin. Ovary central, transversely elongate, initially slightly bilobate but rapidly becoming more compact and irregular (Figs 31-32). Mehlis' gland overlapping or just anterior to vitellarium. Seminal receptacle with rounded distal end and tubular and gradually tapering proximal end. Vaginal pore dorsal to pore of cirrus-sac; most of copulatory part of vagina passing posteriorly to cirrus-sac, straight; lumen encircled by thin cellular sleeve; connected with seminal receptacle by thin and short conductive part (Fig. 32).

Young uterus in mature proglottides well marked, with strong walls, developing antero-dorsally to ovary, initially globular (Fig. 32), often with some irregular incomplete septa. With increasing in size, uterus becoming more irregular, with densification surrounding its anterior wall (Fig. 33); with further development, uterus increasing in size; paruterine organ developing mostly anterior to it but also embracing uterus laterally. No fully developed eggs available.

\section{Remarks}

The present material unambiguously belongs to Notopentorchis Burt, 1938 as diagnosed by Georgiev \& Kornyushin (1994). This genus has recently been thoroughly reviewed and presently comprises eight species, all of them found in swifts from the Old World (Georgiev \& Bray 1991; Dimitrova et al. 2017).

Our material is unfortunately in a rather poor state of conservation and limited as neither a scolex with a full set of hooks nor fully developed gravid proglottides are available. It is, however, sufficient to allow examination of most diagnostic characters. These characters were proved to be sufficiently unique to distinguish it from congeners and to allow for a species description.

Of the eight known species, three belong to a group with rostellar hooks of clearly distinct length in each of the two rostellar rows (Dimitrova et al. 2017). The present material differs from all remaining species by a larger cirrus-sac and larger suckers (Table 5). In addition, it differs from N. collocaliae Burt, 1938 by a larger scolex and rostellum; from $N$. javanica (Hübscher, 1937) by fewer testes; from N. iduncula (Spasskii, 1946), N. caffrapi (Mokhehle, 1951), and N. micropus Singh, 1952 by smaller rostellar hooks (Mokhehle 1951; Singh 1952; Baer 1959; Dimitrova et al. 2017).

So far, no species of Notopentorchis has been reported from Australia. The white-throated needletail Hirundapus caudacutus, hosting the worms described here, however occurs in Central and East Asia and winters in Eastern Australia (Lepage 2017), making this range extension logical. The single occurrence of Notopentorchis in this host was reported as N. vesiculigera (Krabbe, 1882) by Oshmarin (1963) in 15 out 29 birds in the Primorye Region (South-Eastern Russia). Besides its European and African distribution, $N$. vesiculigera clearly differs from our material by its much larger hooks and higher number of testes. We conclude that the present material belongs to an undescribed species that we name Notopentorchis musealis sp. nov. 
Table 5. Comparison of Notopentorchis musealis sp. nov., with the presently known species of Notopentorchis Burt, 1938 (only species with rostellar hooks of similar length in both rows are listed). Values for known species are summarized from various sources as reported in Dimitrova et al. (2017). All species are parasites of Apodidae.

\begin{tabular}{|c|c|c|c|c|c|c|c|c|c|c|c|}
\hline Species & $\begin{array}{c}\text { Type } \\
\text { locality }\end{array}$ & $\begin{array}{c}\text { Body length } \\
\text { (mm) } \\
\times \text { width }\end{array}$ & $\begin{array}{c}\text { Scolex } \\
\text { diameter }\end{array}$ & $\begin{array}{l}\text { Suckers } \\
\text { diameter }\end{array}$ & $\begin{array}{c}\text { Rostellum } \\
\text { diameter }\end{array}$ & $\begin{array}{c}\text { Hooks } \\
\text { number }\end{array}$ & $\begin{array}{c}\text { Anterior } \\
\text { hooks } \\
\text { length }\end{array}$ & $\begin{array}{c}\text { Posterior } \\
\text { hooks } \\
\text { length }\end{array}$ & $\begin{array}{c}\text { Testes } \\
\text { number }\end{array}$ & $\begin{array}{l}\text { Cirrus } \\
\text { sac }\end{array}$ & $\begin{array}{c}\text { Vitellarium } \\
\text { width }\end{array}$ \\
\hline $\begin{array}{l}\text { N. musealis } \\
\text { sp. nov. }\end{array}$ & Australia & $34 \times 590$ & $248-345$ & $170-215$ & $114-139$ & - & $21-23$ & $21-23$ & $5-8$ & $\begin{array}{c}91-112 \times \\
54-64\end{array}$ & $55-76$ \\
\hline $\begin{array}{l}\text { N. collocaliae } \\
\text { Burt, } 1938 \\
\text { (Type species) }\end{array}$ & Sri Lanka & $\begin{array}{l}20-26 \times \\
290-480\end{array}$ & $110-150$ & $65-75$ & $70-82$ & $30-35$ & 24 & 27 & $4-6$ & $\begin{array}{c}30-35 \times \\
16-30\end{array}$ & $40-48$ \\
\hline $\begin{array}{l}\text { N. caffrapi } \\
\text { (Mokhehle, 1951) }\end{array}$ & $\begin{array}{l}\text { South } \\
\text { Africa }\end{array}$ & $20-52 \times 623$ & 316 & 63 & - & - & 28 & - & $4-6$ & $46 \times 28$ & 40 \\
\hline $\begin{array}{l}\text { N. iduncula } \\
\text { (Spasskii, } 1946\end{array}$ & Russia & $\begin{array}{c}18-45 \times \\
340-1000\end{array}$ & $200-262$ & $75-95$ & $81-120$ & $38-44$ & $24-31$ & $27-32.5$ & $4-7$ & $\begin{array}{c}45-70 \times \\
23-35\end{array}$ & 55 \\
\hline $\begin{array}{l}\text { N. javanica } \\
\text { (Hübscher, 1937) }\end{array}$ & $\begin{array}{l}\text { Indonesia } \\
\text { (Java) }\end{array}$ & $\begin{array}{c}26.5 \times \\
327-500\end{array}$ & $170-228$ & $78-102$ & $110-135$ & $44-51$ & 25 & $25-28$ & $8-13$ & $\begin{array}{c}40-120 \times \\
20-50\end{array}$ & $50-83$ \\
\hline $\begin{array}{l}N . \text { micropus } \\
\text { Singh, } 1952\end{array}$ & India & $\begin{array}{l}34-42 \times \\
438-684\end{array}$ & $141-274$ & $90-123$ & $85-131$ & $48-56$ & $21 ?-27$ & $27-31$ & $5-8$ & $\begin{array}{c}72-72 \times \\
27-37\end{array}$ & $35-79$ \\
\hline
\end{tabular}


Family Metadilepididae Spasskii, 1959
Genus Cracticotaenia Spasskii, 1966
Cracticotaenia adelaidae sp. nov.
k.org:act:5F32D506-1E05-421F-B891-DDB9E89F4195

Figs $34-38$

\section{Etymology}

The species name is derived from the name of the City of Adelaide, where the type series was collected.

\section{Material examined}

Holotype

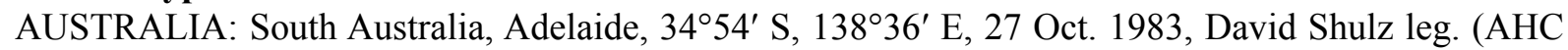
36516).

\section{Paratypes}

AUSTRALIA: 5 specs, same data as for holotype (AHC 36517-36525).

\section{Additional material from the same host}

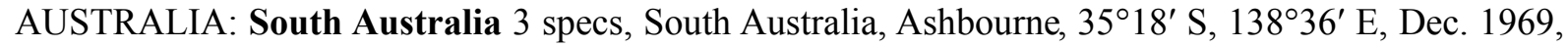
Michael Smyth and Lee leg. (AHC 29591); 2 specs, very fragmented, Coromandel Valley, $35^{\circ} 6^{\prime} \mathrm{S}$, $138^{\circ} 36^{\prime}$ E, 4 Apr. 1969, Michael Smyth leg. (AHC 29592); about 30 specs, Coorong, 36²' S, 139 $33^{\prime}$ E, Oct. 1935, D. Brunswick leg. (AHC 230). - Victoria 2 specs, Torquay, $38^{\circ} 18^{\prime} \mathrm{S}, 144^{\circ} 18^{\prime} \mathrm{E}$, May 1979, Karl Harrigan leg., from Strepera sp. (Artamidae, Passeriformes) (AHC 29596).

\section{Other material}

AUSTRALIA: from Strepera versicolor (Latham, 1801): 6 specs and numerous fragments, no locality, 12 Dec. 1910 (AHC 533). - From Corcorax melanorhamphos (Vieillot, 1817) (Corcoracidae,

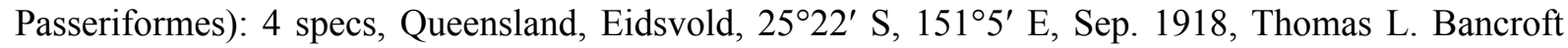
leg. (AHC 531, AHC 29598, co-infection with a Dilepididae, see above); 12 specs, South Australia, Elwomple, $35^{\circ} 17^{\prime} \mathrm{S}, 139^{\circ} 32^{\prime} \mathrm{E}, 19$ Oct. 1937, collector unknown (AHC 3368).

\section{Other comparison material}

Type material of Monopylidium fieldingi (Maplestone \& Southwell, 1923), from Cracticus destructor [now C. torquatus] in Queensland, Townsville (The Natural History Museum, London 1977.11.3.34, 2 slides).

\section{Host}

Gymnorhina tibicen (Latham, 1801) (syn. Cracticus tibicen) (Artamidae, Passeriformes).

\section{Intensity}

Six specimens.

\section{Description}

Body of medium size, with maximum length $35.5 \mathrm{~mm}$ and maximum width $1.3-2.12 \mathrm{~mm}(1.7, \mathrm{n}=6)$ at level of pregravid or early gravid proglottides. Most complete specimen consisting of 240 proglottides. Proglottides craspedote, wider than long, progressively becoming longer, up to slightly longer than wide when gravid. Scolex rounded, not markedly delineated from neck, with diameter 350-475 (407, $\mathrm{n}=8)$, Suckers unarmed, muscular, rounded, 142-198 $(169, \mathrm{n}=35)$ in diameter. Rostellum muscular, 

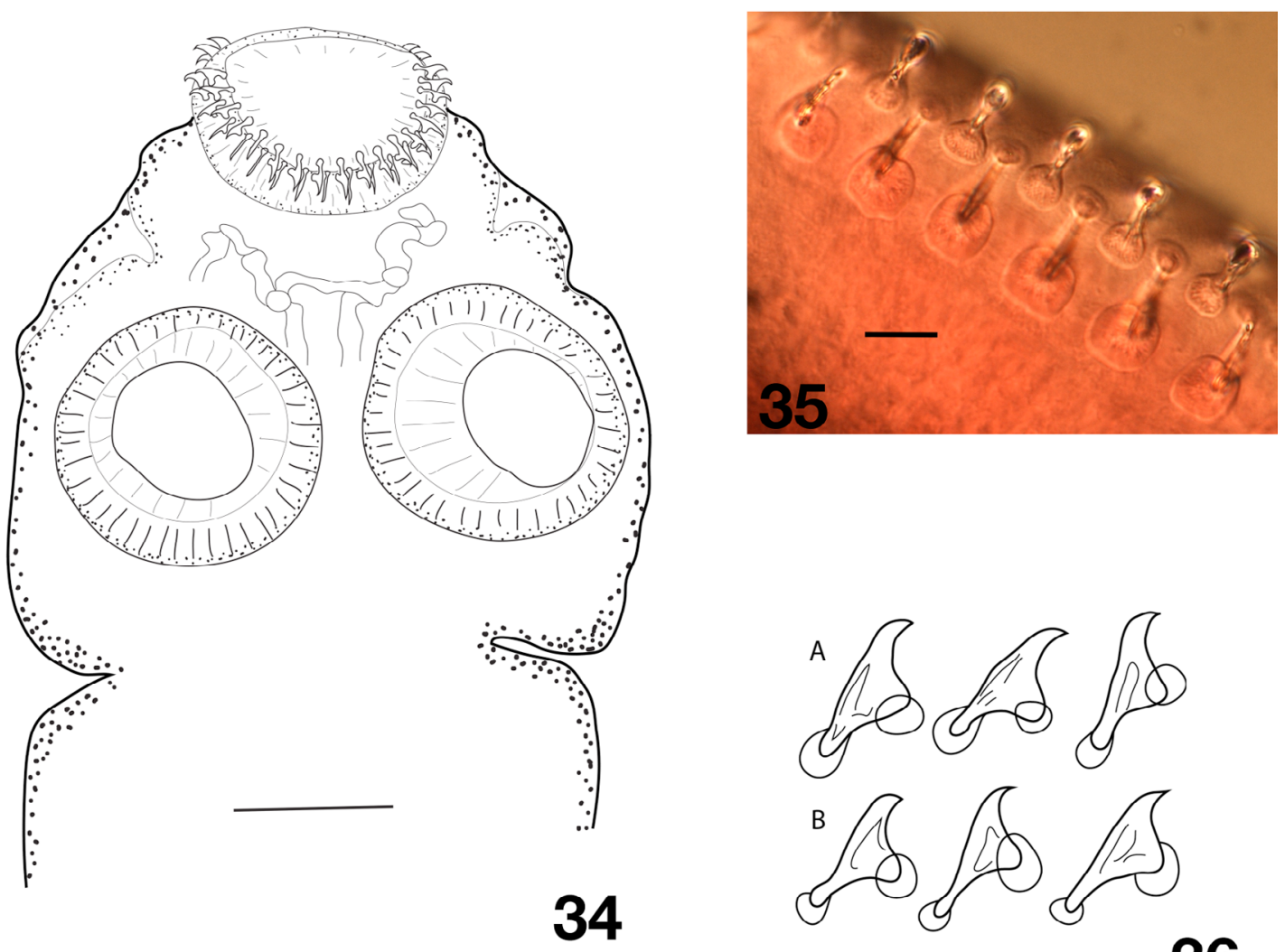

36
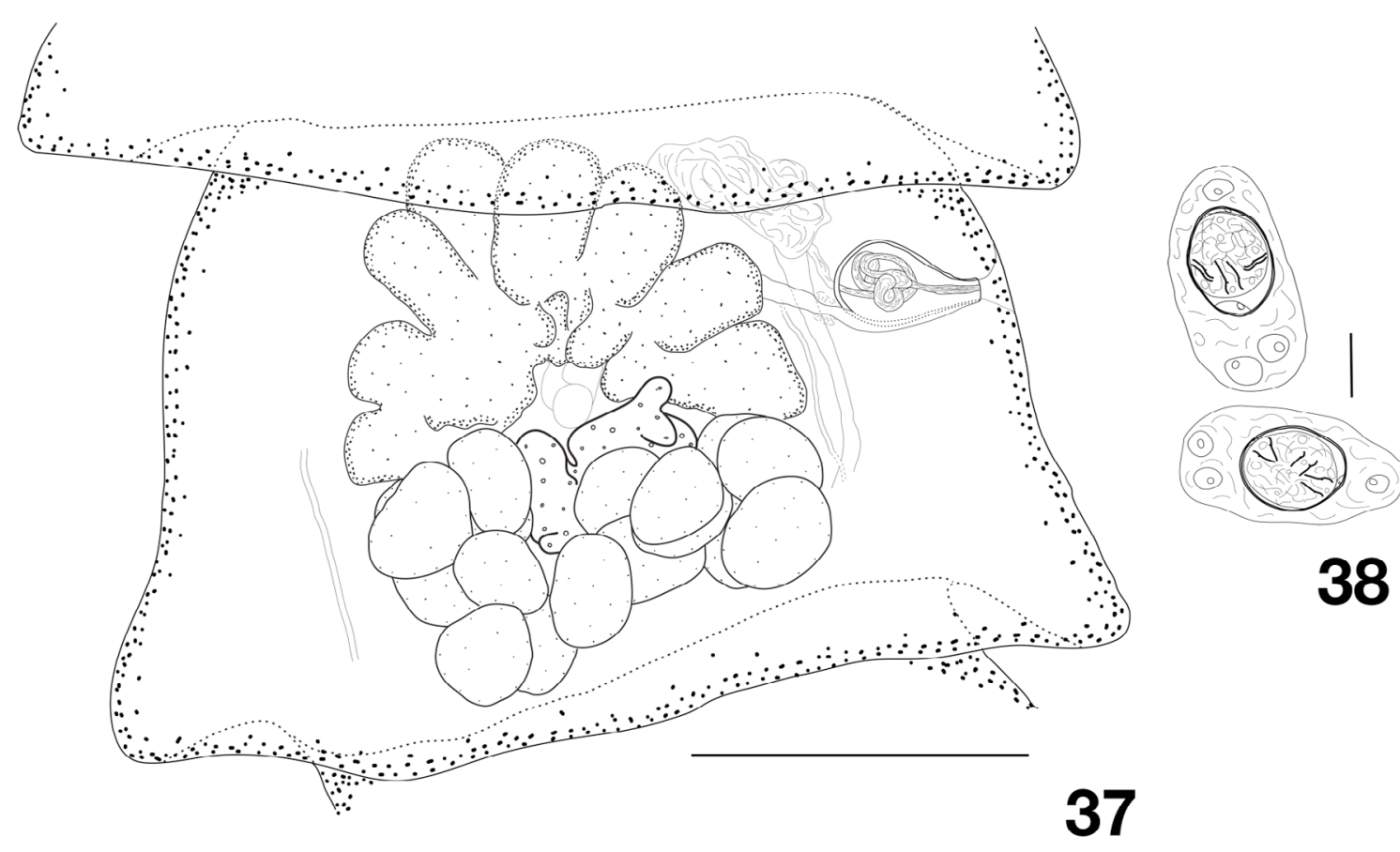

Figs 34-38. Cracticotaenia adelaidae sp. nov. 34. Scolex. 35. Detail of hooks crowns. 36. Hooks: anterior (A) and posterior (B). 37. Mature proglottis. 38. Eggs. Scale bars: $34=100 \mu \mathrm{m} ; 35=10 \mu \mathrm{m}$; $19=500 \mu \mathrm{m} ; 36,38=20 \mu \mathrm{m} ; 37=250 \mu \mathrm{m}$. 
cushion-like 128-188 $(149, \mathrm{n}=8)$ in diameter (Fig. 34). Rostellum bearing double crown of regularly arranged hooks, 52-61 $(56, \mathrm{n}=8)$ in number. Hooks triangular, blade terminating with a short, curved tip. Handles and guards bearing well-developed epiphyses, more developed on guard. Epiphyses of hooks in posterior row clearly larger than those of hooks in anterior row (Figs 35-36). Anterior hooks 23.5-25 (24, $\mathrm{n}=4)$, posterior hooks 21-22 (21.5, $\mathrm{n}=5)$ long. Neck 192-257 (216, $\mathrm{n}=5)$ wide; proglottization starting shortly behind neck. Genital pores unilateral (a single side-switch observed), opening at border of first third of proglottis length margin. Ventral osmoregulatory canals up to 60 wide, connected posteriorly by anastomosis in each proglottis. Dorsal osmoregulatory canals up to 12 wide. Genital ducts passing between osmoregulatory canals. Genital atrium small. Internal organs closely packed in short and wide proglottides, their shape and relative position clearly visible only in very relaxed or extended proglottides.

Testes $12-18(14.5, \mathrm{n}=38)$ in number, in two or, rarely, three layers, in one continuous posterior field, slightly extending laterally up to level of anterior margin of vitellarium (Fig. 37). External vas deferens discrete, convoluted, in antero-poral part of median field, at distance from cirrus-sac. Cirrus-sac short, with strong walls, most often pear-shaped, sometimes more oval, 90-118 $\times 43-58(103 \times 51, \mathrm{n}=57)$, not always reaching poral longitudinal osmoregulatory canals, sometimes slightly overlapping them. Internal vas deferens forming several coils. Cirrus straight with well marked walls, often appearing refractory.

Vitellarium central, compact, often heart-shaped or slightly transversely elongated, variable in shape. Ovary fanlike when not contracted, with deep lobes filling most of anterior part of proglottides. Mehlis' gland central and anterior to vitellarium, connected to seminal receptacle by wide and often clearly visible canal that may become almost as wide as seminal receptacle. Seminal receptacle oval to fusiform, remaining rather small, reaching up to $150 \times 50$, dorsal and between ovary wings or over poral wing, closely to proximal extremity of cirrus-sac. Vagina opens dorsally and slightly posteriorly to male pore, mostly straight, with faint sphincter (Fig. 37).

Uterus starts its development in late mature proglottides as a postero-central and dorsal mass, developing into a lateraly-extended multisaccular and reticulate cavity with well marked wall, then becoming saccate. Outer shell of eggs delicate, oval 62-73 $\times 33-38(68 \times 35, \mathrm{n}=11)$, becoming more circular and irregular in broken proglottides. Embryophore thin and regular, oval, 30-41 $(35, n=23)$ in diameter. Oncosphere subspherical to slightly elongate, $30-40(35.5, \mathrm{n}=18)$ in diameter. Embryonic hooks: central 13-15.5 long $(14.5, \mathrm{n}=14)$ long, lateral 11-13 $(12, \mathrm{n}=17)$ long (Fig. 38).

\section{Remarks}

This material is very similar to Cracticotania fieldingi (Maplestone \& Southwell, 1923), the only species know in the genus. Cracticotania fieldingi was described from Cracticus destructor (now C. torquatus, Artamidae) in Queensland and attributed to Monopylidum by Maplestone \& Southwell (1923). It was later placed in a newly erected monotypic genus by Spasskii (1966) and transferred to the Metadilepididae by Kornyushin \& Georgiev (1994). Our material fits the most recent generic diagnosis of these authors with the notable exception that only a very faint vaginal sphincter is visible. Besides this character, it differs from the single known species in the genus by a smaller number of rostellar hooks (52-61 vs about 80 ), a slightly fewer testes (12-18 vs 16-21) and the differently-shaped and shorter cirrus-sac (globular vs pipette-like and $90-118$ vs 130). It should, however, be noted that we examined the type material of C. fieldingi and the measurements provided by Maplestone \& Southwell (1923) do not fully correspond to our observations. Although only two slides, mostly with gravid proglottides, are available, we noted a somewhat longer cirrus-sac (up to 180) and fewer testes (12-15). This, however, does not prevent the unambiguous separation of our material from $C$. fieldingi and we place it in a new species which we name Cracticotaenia adelaidae sp. nov. 
The specimens found in Corcorax Lesson, 1831 fit the above description of Cracticotaenia adelaidae sp. nov. in Gymnorhina tibicen quite well for most metric and meristic characters that can be observed. The main observed differences are in slightly smaller suckers (123-147 vs 155-198) and possibly more rostellar hooks (62-66 vs 52-61), and the faint vaginal sphincter that could not be observed. Keeping in mind that these observations are based on a limited number of incomplete specimens, we consider for now that these small variations (which may be partially exaggerated due to the poor preservation state of our specimens) are likely to be intraspecific.

Although both belonging to the Corvides (see Jønsson et al. 2016), the hosts of C. adelaidae sp. nov. are not closely related and belong to clades that have probably diverged some 20 to $30 \mathrm{Ma}$ ago (Jønsson et al. 2016; Moyle et al. 2016). The Australian magpie (G. tibicen) and the white winged chough (C. melanorhamphos) have however similar diets and habitats (Russell et al. 2017) as well as overlapping ranges (hosts reported in this study were captured a mere $100 \mathrm{~km}$ apart). This relative phylogenetic proximity and quite similar ecology probably largely explain the hosting of shared parasites.

Cracticotaenia fieldingi (Maplestone \& Southwell, 1923)

Fig. 41

\section{Material examined}

AUSTRALIA: 1 spec., New South Wales, coll. Tonks, Coluvale, 34²4' S, 150 $30^{\prime}$ E, Apr. 1911, T.H. Johnston leg., host: Strepera graculina (Shaw, 1790) (AHC 20393); 2 fragmented specs from small intestine, New South Wales, Taronga Zoo (Sydney), Mar. 2000, Karie Rose leg., host: Strepera versicolor (Latham, 1801) (AHC 28975); 3 specs, New South Wales, Rydal, 3330' S, 1500' E, 4 Feb. 1906, Moreau leg. (AHC 36526).

\section{Hosts}

Strepera graculina (Shaw, 1790) and Strepera versicolor (Latham, 1801) (Artamidae, Passeriformes).

\section{Description}

This material is very similar to $C$. adelaidae described above, in most of its morpho-anatomical characters. A clear difference lies however in the shape and size of copulatory organs. While the cirrussac of $C$. adelaidae is short and globular, it is much more elongated and cylindrical here, always clearly
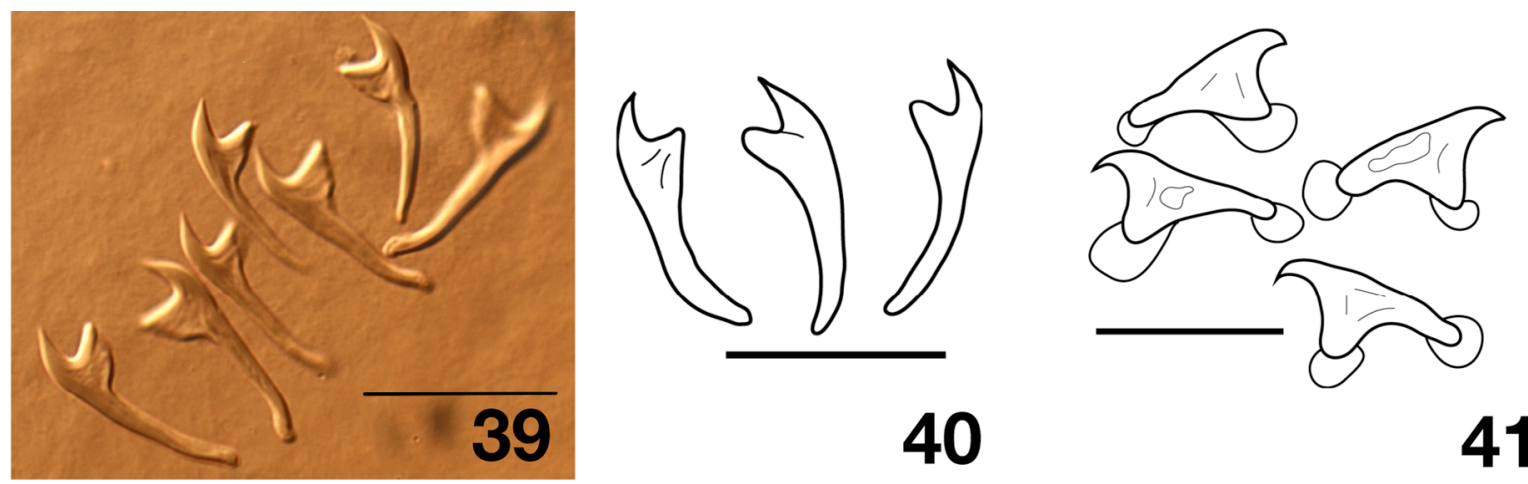

Figs 39-41. 39. Dilepididae genus sp. Hooks. 40. Passerilepis sp. Hooks. 41. Cracticotaenia fieldingi (Maplestone \& Southwell, 1923) Hooks. Scale bars: 39-41 = $20 \mu \mathrm{m}$. 
crossing the excretory canals and 70\% longer, reaching $155-193 \times 30-40(176 \times 36, \mathrm{n}=20)$. Another discriminating character is the presence of a massive terminal vaginal sphincter, which is absent in C. adelaidae. Hooks are 23-25 $(24, \mathrm{n}=9)$ and 22-24 (22.5, $\mathrm{n}=9)$ long (Fig. 41). The material is however macerated and difficult to interpret, and it is not possible to associate rostellar hook counts and other measurements to specimens for which anatomy is available. The few available specimens from AHC 36526 include some long ones (up to $39.2 \mathrm{~mm}$ ), including one with a complete scolex (scolex diameter 525, suckers diameter 200-220, about 88 hooks). A vaginal sphincter is present and cirrus-sacs are of a similar shape as $C$. fieldingi but larger $(235-300 \times 38-65)$.

Globally, this material corresponds to the description of C. fieldingi from Cracticus destructor [= C. torquatus] as described by Maplestone \& Southwell (1923) and observed by ourselves (see above). It should, however, be noted that $C$. fieldingi has not only been described in a different host, but also from a locality in Queensland which is some $1500 \mathrm{~km}$ north of the New South Wales stations considered here. The available specimens do not allow for a detailed study, but the variability observed in our different samples suggest a possible diversification of Cracticotaenia in the Artamidae.

\section{Discussion}

The rich and diversified avian fauna of Australia is undoubtedly hosting a wide variety of cestodes that we safely assume to reach several hundreds of species. Unfortunately, with a few dozens species reported, this area of the country's biodiversity remains both unknown and unexplored. The fact that our study of the SAMA collections allowed to describe seven new taxa from common and abundant host species allows at least two comments. First, museum collections, even older ones, are important tools for the discovery of new taxa, including common but neglected ones. Second, these discoveries only represent a tiny proportion of the real-life diversity, and museum specimens are no substitutes for the exploration of the living world. The diversity, ease of study and access to diverse sources of characters are only guaranteed by fresh collections. In this work, for example, we did not try any sequencing of our samples, because the limited chances of success with these long-preserved specimens, together with the small amount of available material made us deem such attempt too risky. Obviously, a methodical, state of the art collection program would allow for a much easier access to all categories of characters, including molecular, to describe new taxa.

\section{Acknowledgements}

We are grateful to Leslie Chisholm, Lesley Warner and the late Ian Witthington (Adelaide) as well as to Ian Beveridge (Melbourne) for their welcome and for facilitating the study of this collection. Alice Cibois (Geneva) provided useful ornithological information and literature. Oksana Greben (Kiev), Arseny Makarikov (Novosibirsk) and Gergana Vasileva (Sofia) helped with access to Russian literature. Janik Pralong (Geneva) stained and mounted specimens. Two anonymous reviewers provided insightful suggestions. All are heartily thanked. We acknowledge support from NSF-PBI, USA awards (DEB 0818696 and 0818823 ) and from the Natural History Museum of Geneva.

\section{References}

Baer J.G. 1956. Parasitic helminths collected in West Greenland. Meddelelser om Grønland 124: 1-55.

Baer J.G. 1959. Exploration des Parcs Nationaux du Congo Belge. Mission J.G. Baer - W. Gerber (1958). Helminthes parasites. Institut des Parcs Nationaux du Congo Belge, Bruxelles.

Bona F.V. 1975. Étude critique et taxonomique des Dilepididae Fuhrm., 1907 (Cestoda) parasites des Ciconiiformes. Considérations sur la spécificité et la spéciation. Monitore Zoologico Italiano N.S. Monografia 1: 1-750. 
Bona F.V. 1994. Family Dilepididae Railliet \& Henry, 1909. In: Khalil L.F., Jones A. \& Bray R.A. (eds) Keys to the Cestode Parasites of Vertebrates: 443-554. CAB International, Wallingford.

Borgarenko L. 1981. Helminths of Birds in Tadzhikistan. Book 1. Cestodes. Donish, Dushanbe. [In Russian.]

Burt D.R.R. 1940. New species of cestodes from Charadriiformes, Ardeiformes and Pelecaniformes in Ceylon. Ceylon Journal of Science. Section B. Zoology and Geology 22: 1-63.

Caira J.N., Jensen K., Georgiev B.B., Kuchta R., Littlewood D.T.J., Mariaux J., Scholz T., Tkach V.V. \& Waeschenbach A. 2017. An overview of tapeworms from vertebrate bowels of the earth. In: Caira J.N. \& Jensen K. (eds). Planetary Biodiversity Inventory (2008-2017): Tapeworms from Vertebrate Bowels of the Earth: 1-20. University of Kansas, Lawrence.

Clark D.T. 1952. Three new dilepidid cestodes, Dictymetra numenii n. gen. sp. nov.; Dictymetra paranumenii sp. nov. and Anomotaenia filovata sp. nov. Proceedings of the Helminthological Society of Washington 19: 18-27.

Clerc W. 1911. Materials on the helminthology of Orlovskaya Governorate - Matériaux pour la faune helminthologique du gouvernement d'Orel. Materialy k Poznaniyu Prirody Orlovskoy Gubernii. Kiev and Orel: Obschestvo dlya Izsledovaniya Prirody Orlovskoy Gubernii 15: 1-24. [In Russian and French.]

Cooper C.L. \& Crites J.L. 1974. The helminth parasites of the blue jay, Cyanocitta cristata bromia, from South Bass Island, Ohio. Canadian Journal of Zoology 52: 1421-1423. https://doi.org/10.1139/z74-180

Dimitrova Y.D., Mariaux J. \& Georgiev B.B. 2013. Pseudangularia gonzalezi sp. nov. and Gibsonilepis swifti (Singh, 1952) n. g., n. comb. (Cestoda, Dilepididae) from the House Swift, Apus affinis (J.E. Gray) (Aves, Apodiformes) from Franceville, Republic of Gabon. Systematic Parasitology 86: 215-233. https://doi.org/10.1007/s11230-013-9445-4

Dimitrova Y., Mariaux J. \& Georgiev B. 2017. Redescriptions of four Palaeotropical species of the cestode genus Notopentorchis Burt, 1938 (Cyclophyllidea: Paruterinidae). Zootaxa 4290: 61-82.

https://doi.org/10.11646/zootaxa.4290.1.3

Ericson P.G., Jansén A.-L., Johansson U.S. \& Ekman J. 2005. Inter-generic relationships of the crows, jays, magpies and allied groups (Aves: Corvidae) based on nucleotide sequence data. Journal of Avian Biology 36: 222-234. https://doi.org/10.1111/j.0908-8857.2001.03409.x

Fuhrmann O. 1908. Nouveauxs ténias d'oiseaux. Revue suisse de Zoologie 16: 27-73. https://doi.org/10.5962/bhl.part.37382

Fuhrmann O. 1911. Vogelcestoden der Aru-Inseln. Abhandlungen der Senckenbergischen Naturforschenden Gesellschaft 34: 251-266.

Fuhrmann O. \& Baer J.G. 1943. Mission biologique Sagan-Omo (Ethiopie méridionale), 1939, dirigée par le professeur Eduardo Zavattari. Cestodes. Bulletin de la Société neuchâteloise de Sciences naturelles 68: $113-140$.

Gelis S., Spratt D.M. \& Raidal S.R. 2011. Neuroangiostrongyliasis and other parasites in tawny frogmouths (Podargus strigoides) in south-eastern Queensland. Australian Veterinary Journal 89: 4750. https://doi.org/10.1111/j.1751-0813.2010.00660.x

Georgiev B.B. \& Bray R.A. 1991. Notopentorchis cyathiformis (Frölich, 1791) n. comb. and N. iduncula (Spasskii, 1946) (Cestoda: Paruterinidae) from Palaearctic swifts (Aves: Apodiformes), with a review of the genus Notopentorchis Burt, 1938. Systematic Parasitology 20: 121-133.

https://doi.org/10.1007/bf00007388 
Georgiev B.B. \& Kornyushin V.V. 1994. Family Paruterinidae Fuhrmann, 1907 (sensu lato). In: Khalil L.F., Jones A. \& Bray R.A. (eds) Keys to the Cestode Parasites of Vertebrates: 559-584. CAB International, Wallingford.

Georgiev B.B. \& Vaucher C. 2003. Revision of the Metadilepididae (Cestoda: Cyclophyllidea) from Caprimulgiformes (Aves). Revue suisse de Zoologie 110: 491-532.

https://doi.org/10.5962/bhl.part.80195

Georgiev B.B., Kornyushin V.V. \& Genov T. 1987. Choanotaenia pirinica sp. n. (Cestoda, Dilepididae) - a parasite of the Alpine Chough in Bulgaria. Vestnik Zoologii 1987: 3-7. [In Russian.]

Haring E., Däubl B., Pinsker W., Kryukov A. \& Gamauf A. 2012. Genetic divergences and intraspecific variation in corvids of the genus Corvus (Aves: Passeriformes: Corvidae) - a first survey based on museum specimens. Journal of Zoological Systematics and Evolutionary Research 50: 230-246.

https://doi.org/10.1111/j.1439-0469.2012.00664.x

Johnston T.H. 1909. On the anatomy of Monopylidium passerinum Fuhrmann. Journal and Proceedings of the Royal Society of New South Wales 43: 405-411.

Johnston T.H. 1913. Notes on some Entozoa. Proceedings of the Royal Society of Queensland 24: 63-91.

Jønsson K.A., Fabre P.-H., Kennedy J.D., Holt B.G., Borregaard M.K., Rahbek C. \& Fjeldså J. 2016. A supermatrix phylogeny of corvoid passerine birds (Aves: Corvides). Molecular Phylogenetics and Evolution 94: 87-94. https://doi.org/10.1016/j.ympev.2015.08.020

Joyeux C. \& Baer J.G. 1955. Cestodes d'oiseaux récoltés dans le centre de la France. Bulletin de la Société zoologique de France 80: 174-196.

Joyeux C., Baer J.G. \& Martin R. 1937. Sur quelques helminthes de la Somalie-Nord (Deuxième note). Bulletin de la Société de Pathologie exotique 30: 416-423.

Komisarovas J., Georgiev B.B. \& Mariaux J. 2007. Redescriptions of Monopylidium exiguum (Dujardin, 1845) and M. albani (Mettrick, 1958) n. comb. (Cestoda: Dilepididae) from European passerine birds. Systematic Parasitology 68: 87-96. https://doi.org/10.1007/s11230-007-9103-9

Kornyushin V.V. \& Georgiev B.B. 1994. Family Metadilepididae Spasskii, 1959. In: Khalil L.F., Jones A. \& Bray R.A. (eds) Keys to the cestode parasites of vertebrates: 585-593. CAB International, Wallingford.

Kornyushin V.V., Salamatin R.V., Greben O.B. \& Georgiev B.B. 2009. Spiniglans sharpiloi sp. n. (Cestoda, Dilepididae), a parasite of the common magpie, Pica pica, in the Palaearctic. Vestnik Zoologii Supplement 23: 85-93.

Krabbe H. 1869. Bidrag til kundskab om fuglenes baendelorme. Videnskabelige Selskab Skrifter, 5. raekke, Naturvidenskabelig og Mathematisk Afdel 8: 251-389.

Kugi G. 1996. Three new species of cestodes, Sobolevitaenia turdi, Sobolevitaenia oitaenis, and Neyraia turdi, from a Ground Thrush, Turdus sibiricus at Oita Prefecture, Southern Japan. Japanese Journal of Parasitology 45: 105-111.

Kugi G. 2000. Sobolevitaenia japonensis sp. nov. (Dilepididae: Dilepidinae) from a dusky thrush, Turdus naumanni eunomus Temminck, in Oita Prefecture, Japan. Parasitology International 48: 199203. https://doi.org/10.1016/s1383-5769(99)00016-1

Lepage D. 2017. Avibase - the World Bird Database. Available from http://avibase.bsc-eoc.org [accessed 1 Nov. 2017].

Lincicome D.R. 1939. A new tapeworm, Choanotaenia iola, from the robin. The Journal of Parasitology 25: 203-206. https://doi.org/10.2307/3272504 
Maplestone P. \& Southwell T. 1923. Notes on Australian Cestodes. VII. Annals of Tropical Medicine and Parasitology 17: 317-331. https://doi.org/10.1080/00034983.1923.11684361

Mariaux J., Tkach V.V., Vasileva G.P., Waeschenbach A., Beveridge I., Dimitrova Y.D., Haukisalmi V., Greiman S.E., Littlewood D.T.J., Makarikov A.A., Phillips A.J., Razafiarisolo T., Widmer V. \& Georgiev B.B. 2017. Cyclophyllidea van Beneden in Braun, 1900. In: Caira J. N. \& Jensen K. (eds) Planetary Biodiversity Inventory (2008-2017): Tapeworms from Vertebrate Bowels of the Earth: 77148. University of Kansas, Lawrence.

Matevosyan E.M. 1963. Dilepidoidea-Tapeworms of Domestic and Wild Animals. Izdatel'stvo Akademii Nauk SSSR, Moscow. [In Russian.]

Mawson P.M., Angel L.M. \& Edmonds S.J. 1986. A checklist of helminths from Australian birds. Records of the South Australian Museum 19: 219-325.

McOrist S. \& Scott P.C. 1989. Parasitic enteritis in superb lyrebirds (Menura novaehollandiae). Journal of Wildlife Diseases 25: 420-421. https://doi.org/10.7589/0090-3558-25.3.420

Meggitt F.J. 1927. Report on a collection of Cestoda, mainly from Egypt. Part II. Cyclophyllidea: Family Hymenolepididae. Parasitology 19: 420-450. https://doi.org/10.1017/S0031182000005904

Mettrick D.F. 1958. Helminth parasites of Hertfordshire birds II - Cestoda. Journal of Helminthology 32: 159-194. https://doi.org/10.1017/s0022149x00019568

Mettrick D.F. \& Beverley Burton M. 1962. A new cestode, Anomotaenia caenodex sp. nov. from a Mistle Thrush, Turdus viscivorus viscivorus (L.). Journal of Helmintholology 36: 157-160. https://doi.org/10.1017/s0022149x00022446

Mokhehle 1951. Parasites of the swift Caffrapus caffer caffer (Roberts) with descriptions of one new genus and eight new species. Fort Hare Papers 1: 302-396.

Moyle R.G., Oliveros C.H., Andersen M.J., Hosner P.A., Benz B.W., Manthey J.D., Travers S.L., Brown R.M. \& Faircloth B.C. 2016. Tectonic collision and uplift of Wallacea triggered the global songbird radiation. Nature Communications 7: 1-7. https://doi.org/10.1038/ncomms12709

O’Callaghan M.G., Davies M. \& Andrews R.H. 2000. Species of Raillietina Fuhrmann, 1920 (Cestoda: Davaineidae) from the emu, Dromaius novaehollandiae. Transactions of the Royal Society of South Australia 124: 105-116.

O'Callaghan M.G., Andrews R.H., Davies M. \& Spratt, D.M. 2001. Species of Raillietina Fuhrmann, 1920 (Cestoda: Davaineidae) from the southern cassowary (Casuarius casuarius). Transactions of the Royal Society of South Australia 125: 133-139.

Oshmarin P. 1963. Helminths of mammals and birds in the Primorsk region. Izdatelsvo Akademii Nauk SSSR, Moscow. [In Russian.]

Pfaffenberger G.S. \& Butler W.F. 1981. Helminths recovered from the white-necked raven (Corvus cryptoleucus Couch) in Eastern New Mexico. Journal of Wildlife Diseases 17: 563-566.

https://doi.org/10.7589/0090-3558-17.4.563

Russell E., Rowley I. \& Christie D.A. 2017. Australian Magpie (Gymnorhina tibicen) and Whitewinged Chough (Corcorax melanorhamphos). In: del Hoyo J., Elliott A., Sargatal J., Christie D.A. \& de Juana E. (eds.) Handbook of the Birds of the World Alive. Lynx Edicions, Barcelona. Available from http://www.hbw.com/node/60621 [accessed 15 Sep. 2017].

Salamatin R.V. 1999. The cestodes of the genus Spiniglans (Dilepididae) from the corvid birds (Corvidae) from Ukraine. Vestnik Zoologii 33: 75-81. [In Russian.] 
Schmidt G.D. 1972. Cyclophyllidean cestodes of Australian birds, with three new species. The Journal of Parasitology 58: 1085-1094. https://doi.org/10.2307/3278142

Schmidt G.D. 1986. CRC Handbook of Tapeworm Identification. CRC Press Inc., Boca Raton, Florida.

Singh K.S. 1952. Cestode parasites of birds. Indian Journal of Helminthology 4: 1-72.

Singh K.S. 1964. On six new avian cestodes form India. Parasitology 54: 177-194.

https://doi.org/10.1017/s0031182000074461

Southwell T. 1922. Cestodes from Indian birds with a note on Ligula intestinalis. Annals of Tropical Medicine \& Parasitology 16: 355-382. https://doi.org/10.1080/00034983.1922.11684330

Spasskaya L.P. \& Makarenko V.K. 1965. A new genus of cestodes from birds - Sobolevitaenia n. gen. In: Parasitic worms of domestic and wild animals: Papers on helminthology presented to Prof. A. A. Sobolev on the 40th anniversary of his scientific and teaching activity: 298-302. Dalnevostochnii Gosudarstvenniy Universiet, Vladivostok. [In Russian.]

Spasskaya L.P. \& Spasskii A. 1973. Dictymetra belopolskaje, sp. n. (Cestoda: Dilepididae) a new species of cestode in birds. Izvestiya Akademii Nauk Moldovskoi SSR (Biologicheskie i Khimicheskie Nauki) 4: 63-68. [In Russian.]

Spasskaya L.P. \& Spasskii A. 1977. Cestodes of Birds in the USSR. Dilepididae of Terrestrial Birds. Izdate'stvo Nauka, Moscow. [In Russian.]

Spasskaya L.P. \& Spasskii A. 1978. Cestodes of Birds in the USSR. Dilepididae of Aquatic Birds. Izdate'stvo Nauka, Moscow. [In Russian.]

Spasskii A. A. 1966. On the heterogeneity of the genus Anomotaenia (Cestoda: Dilepididae). Doklady Akademii Nauk USSR 69: 1483-1485. [In Russian.]

Spasskii A.A. 1993. On the structure of species of genus Monopylidium (Dilepididae) and its position in Cestoda system. Izvestiya Akademii Nauk Respubliki Moldova Biologicheskie i Khimicheskie Nauki 1: 42-49. [In Russian.]

Spasskii A.A. \& Borgarenko L.F. 1973. Stenovaria n. g. (Cestoda: Dilepididae) - a new genus of cestodes from the stone curlew. Izvestiya Akademii Nauk Tadzhikskoi SSR, Biologicheskie Nauk 2: 87-93. [In Russian.]

Spasskii A.A. \& Konovalov Y.N. 1986. Three species of tapeworms of the genus Monopylidium (Cestoda, Dilepididae) from terrestrial birds of Chukotska. Vestnik Zoology 4: 6-12. [In Russian.]

Voser I. \& Vaucher C. 1988. Helminthes parasites du Paraguay XIV. Cestodes parasites de Turdidae et description d'Anomotaenia korochirei n. sp. Revue suisse de Zoologie 95: 1137-1161.

https://doi.org/10.5962/bhl.part.81957

Yamaguti S. 1956. Studies on the Helminth Fauna of Japan. Part 50. Cestodes of Birds, III. Published by the author, Tokyo.

Manuscript received: 23 January 2018

Manuscript accepted: 26 March 2018

Published on: 31 May 2018

Topic editor: Rudy Jocqué

Desk editor: Pepe Fernández 
Printed versions of all papers are also deposited in the libraries of the institutes that are members of the EJT consortium: Muséum national d'Histoire naturelle, Paris, France; Botanic Garden Meise, Belgium; Royal Museum for Central Africa, Tervuren, Belgium; Natural History Museum, London, United Kingdom; Royal Belgian Institute of Natural Sciences, Brussels, Belgium; Natural History Museum of Denmark, Copenhagen, Denmark; Naturalis Biodiversity Center, Leiden, the Netherlands; Museo Nacional de Ciencias Naturales-CSIC, Madrid, Spain; Real Jardín Botánico de Madrid CSIC, Spain; Zoological Research Museum Alexander Koenig, Bonn, Germany. 